\title{
Re-equilibration of fluid inclusions in diagenetic-anchizonal rocks of the Ciñera-Matallana coal basin (NW Spain)
}

\author{
F. AYLLÓN ${ }^{1}$, R. J. BAKKER ${ }^{2}$ AND L. N. WARR ${ }^{1}$ \\ ${ }^{1}$ Geologisch-Paläontologisches Institut, Ruprecht-Karls-Universität, Im Neuenheimer Feld 234, D-69120 Heidelberg, Germany; \\ ${ }^{2}$ Mineralogy \& Petrology Institute of Geosciences, University of Leoben, Austria
}

\begin{abstract}
Thermally re-equilibrated fluid inclusions are reported in natural fissure quartz (qtz1) from polymineralic veins in the diagenetic-anchizonal clastic sedimentary rocks of the Ciñera-Matallana coal basin (Variscan, NW Spain). Euhedral quartz formed during early fissure opening from an immiscible fluid mixture composed of a low salinity aqueous solution and $\mathrm{a} \mathrm{CH}_{4}$-rich vapour phase, at temperatures of about $110-120^{\circ} \mathrm{C}$ and pressures ranging from 15 to $56 \mathrm{MPa}$. Five textural types of re-equilibration are recognised in progressive order of inclusion modification: scalloped, hairy, annular-ring shaped, haloes and decrepitation clusters. These textures resulted from a combination of brittle fracturing and dissolution and re-precipitation of quartz, with preferential loss of water. The thermal peak was short-lived, but was high enough to induce extensive decrepitation of fluid inclusions in vein quartz throughout the entire basin. Enhanced temperatures can be related to the intrusion of diorites in the basin. Careful analysis of textural features in fluid inclusions from diagenetic and very low-grade metamorphism environments constitutes a useful tool for recording basin thermal history.
\end{abstract}

Key words: fissure quartz, fluid inclusion textures, re-equilibration, thermal peak

Received 18 March 2002; accepted 16 September 2002

Corresponding author: Fernando Ayllón, Geologisch-Paläontologisches Institut, Ruprecht-Karls-Universität, Im Neuenheimer Feld 234, D-69120 Heidelberg, Germany.

E-mail: Fernando.Ayllon@urz.uni-heidelberg.de. Tel: +496221544891/544835. Fax: +496221545503.

Geofluids (2003) 3, 49-68.

\section{INTRODUCTION}

The ideal isochoric model for the interpretation of fluid inclusions assumes that they behave as compositionally and volumetrically closed systems after formation. When such conditions are fulfilled, the inclusions preserve the original parent fluid, which in many cases represents that associated with mineral growth. Re-equilibration is a term that encompasses any type of post-entrapment modification that affects fluid inclusions and results in a departure from the original isochore for the inclusion. This phenomenon has been a matter of intense investigation by fluid inclusion researchers due to the importance of evaluating any changes that may invalidate the interpretation of $P-T-V-X$ formation conditions. Quartz, both natural and synthetic, has received by far the most attention (Pecher 1981; Gratier 1982; Sterner \& Bodnar 1989; Bakker \& Jansen 1990).

Re-equilibration of fluid inclusions follows several intermediate and progressive steps, namely, stretching, formation of irregular cavity walls, necking down, leakage and finally, partial and total decrepitation (e.g. Roedder 1984). Experimental research has provided an insight into the variety of textural changes of fluid inclusions in natural rock. Such studies characterise the types of textures related to specific reequilibration paths, and evaluate the relative importance of different factors that influence re-equilibration. Size and shape of the inclusion, its fluid composition and the physical and chemical properties of the host mineral have been shown to be important.

Textural variations caused by internal overpressure of fluid inclusions are considered to be limited. Stretching, i.e. inelastic deformation of the inclusion wall, is not a feature that will be texturally preserved in natural rock (e.g. Bodnar \& Bethke 1984). Internal overpressure may cause a fluid filled cavity to explode (decrepitation), if it exceeds the lattice strength of the host mineral (Leroy 1979; Gratier \& Jenatton 1984; Bodnar et al. 1989; Vityk et al. 1994, 1995). Such brittle deformation changes the shape of the inclusion cavity creating cracks, 
which subsequently can be modified by re-crystallisation to form characteristic textures, such as extremely irregular shapes and planes of satellite inclusions (i.e. decrepitation clusters). Pécher (1981) and Bakker \& Jansen (1991) documented the formation of cracks at higher confining pressures, produced both during internal over- and underpressure experiments, although some controversy exists as to the formation of decrepitation clusters under experimental conditions (Sterner \& Bodnar 1989). Re-equilibration textures caused by internal underpressure are well documented and display a wide variety of morphologies. Progressive stages of modification are recognised as the parent inclusion is redistributed into the host mineral. Initially, scalloped textures may develop by intense dissolution of the walls, resulting in highly irregular and rough inclusion morphologies (Pécher 1981; Bakker \& Jansen 1991; Vityk \& Bodnar 1995; Vityk et al. 1995). Arc, hook, ring and semi-annular textures develop during advanced re-equilibration (Pécher 1981; Vityk \& Bodnar 1995). Audétat \& Gunther (1999) observed similar structures in natural samples, where the migration of inclusions was suggested to cause the formation of tails, giving the inclusions an arc-like appearance. Three-dimensional inclusion clusters or haloes of small secondary inclusions result from further re-equilibration (e.g. Vityk \& Bodnar 1995). Such clusters are also reported as implosion haloes (e.g. Sterner \& Bodnar 1989) or sweat haloes (e.g.
Audétat \& Günther 1999). During the most advanced stages of re-equilibration, highly irregular dendritic-like haloes develop with near closing of the parent inclusion (Sterner \& Bodnar 1989; Vityk \& Bodnar 1995). The original fluid of the parent inclusion is re-distributed in an irregular-shaped cloud of numerous small secondary inclusions.

Fluid inclusion studies of decrepitation features in natural samples have focused on case studies from ore deposits (Foley et al. 1989) and from high to medium grade metamorphic environments (Swanenberg 1980; Boullier et al. 1991; Hurai \& Horn 1992; Vityk et al. 1996; Küster \& Stöckhert 1997). These studies address the use of decrepitated inclusions as indicators for thermal cracking of minerals (quartz) and as geobarometers for tectonic reconstruction in orogens. In contrast, decrepitation in diagenetic and very low-grade metamorphic environments (subgreenschist facies) has received little attention. Here, studies have focused on the resetting of homogenisation temperatures within calcite and quartz cements due to stretching of inclusions induced by overheating and burial (Goldstein 1986; Burrus 1987; Osborne \& Haszeldine 1993, 1995).

In this study we report and interpret $P-T-V-X$ data obtained from natural fluid inclusions in quartz-carbonate, deformation-related veins located within diagenetic-anchizonal grade clastic rocks of the Ciñera-Matallana coal basin

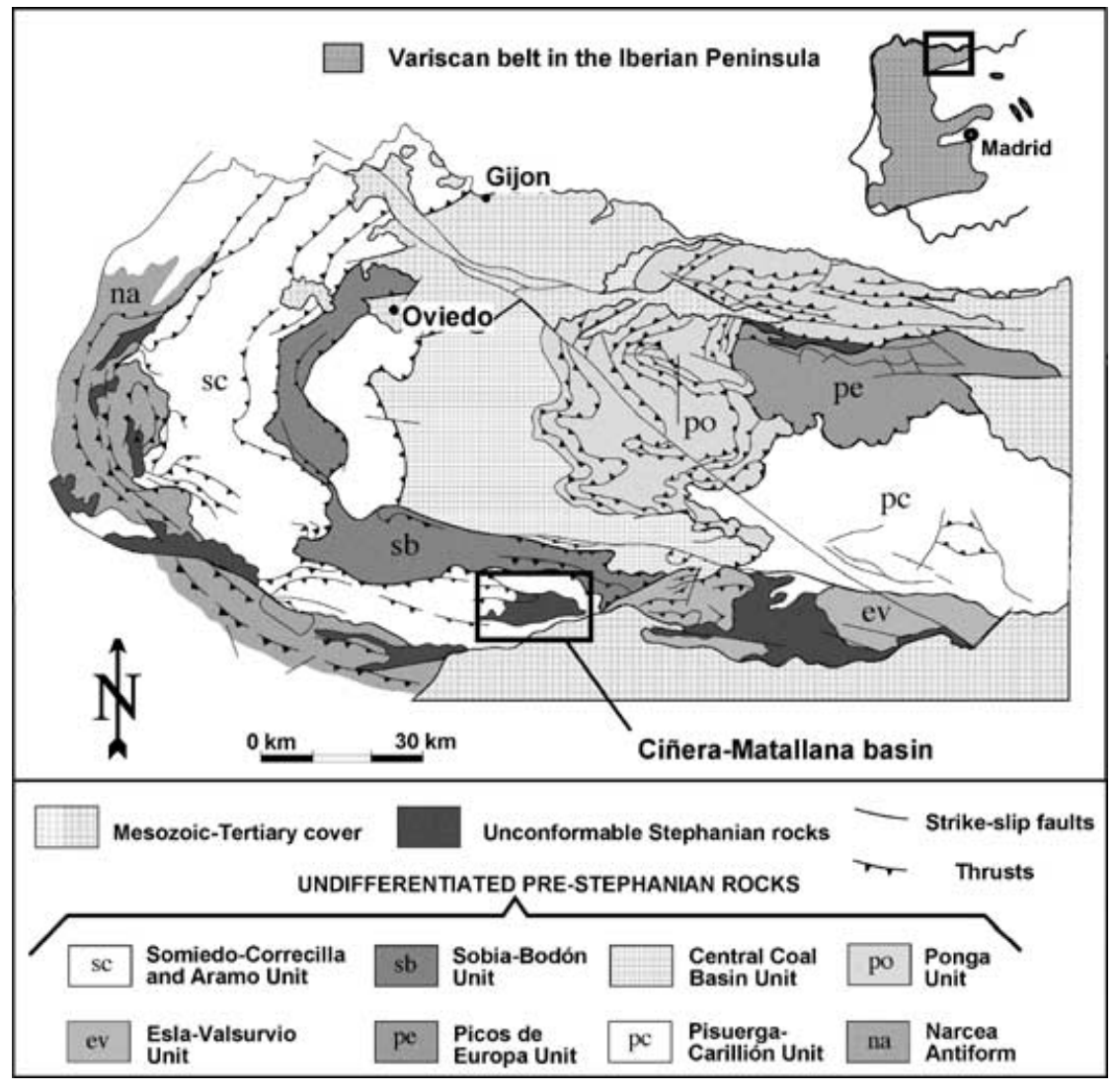

Fig. 1. Geological sketch map of the Cantabrian Zone showing the main thrusts and the Variscan tectonostratigraphic units (after Pérez-Estaun et al. 1988). Note the distribution of the discordant Stephanian rocks within pull-apart basins around the Asturian arc. The framed area encloses the Ciñera-Matallana basin. 
(Cantabrian Zone, NW Spain). This discordant Stephanian pull-apart basin was characterised by a higher geothermal gradient than in the surrounding pre- and syn-orogenic Palaeozoic rocks. The investigated fluid inclusion re-equilibration textures within the fissure quartz are considered as excellent indicators of the high heat flow conditions experienced within this diagenetic to low temperature metamorphic environment.

\section{GEOLOGICAL SETTING AND FIELD RELATIONS}

The Ciñera-Matallana (CM) limnic coal basin lies in the south of the Cantabrian Zone, a fold and thrust belt situated in the external portion of the Variscan orogenic belt of NW Spain (Fig. 1). This small pull-apart basin has a complex halfgraben structure, extending $12 \mathrm{~km}(\mathrm{E}-\mathrm{W})$ along strike and
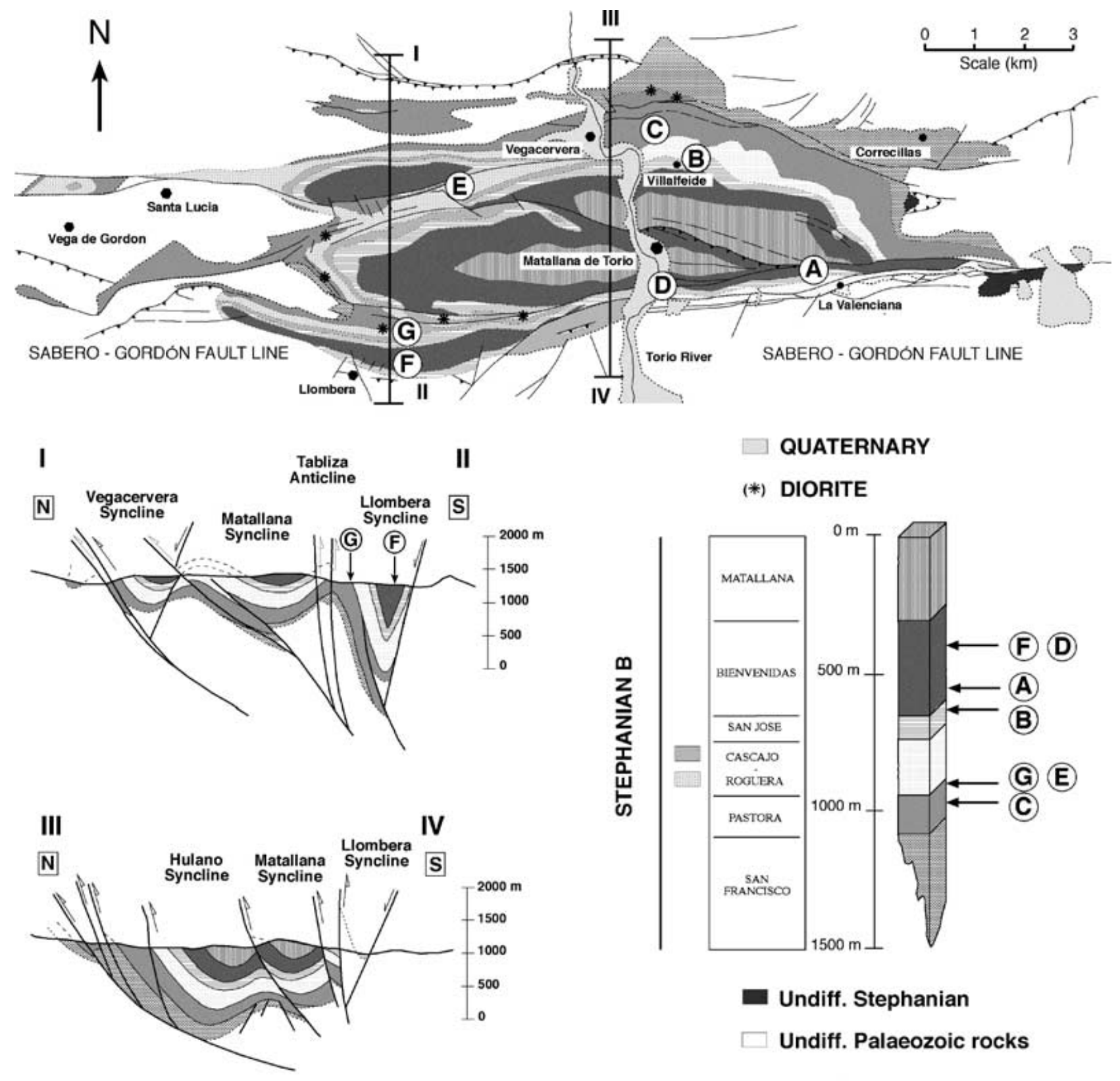

QUATERNARY

(*) DIORITE

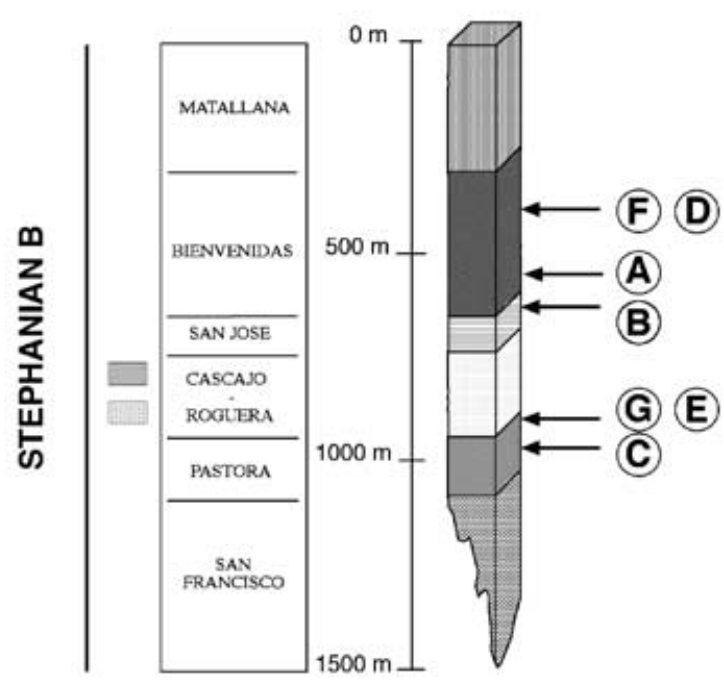

Undiff. Stephanian

Undiff. Palaeozoic rocks

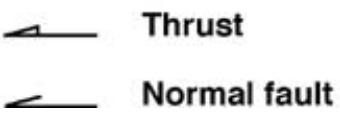

Fig. 2. Geological map, cross-sections and stratigraphic column of the Ciñera-Matallana coal basin (CM), see text for further details. The points A-G identified on the map correspond to different outcrop localities used in this study (see Table 1). Modified from data of Wagner \& Artieda (1970), Lobato et al. (1984), Alonso et al. (1990) and Villegas (1996). 


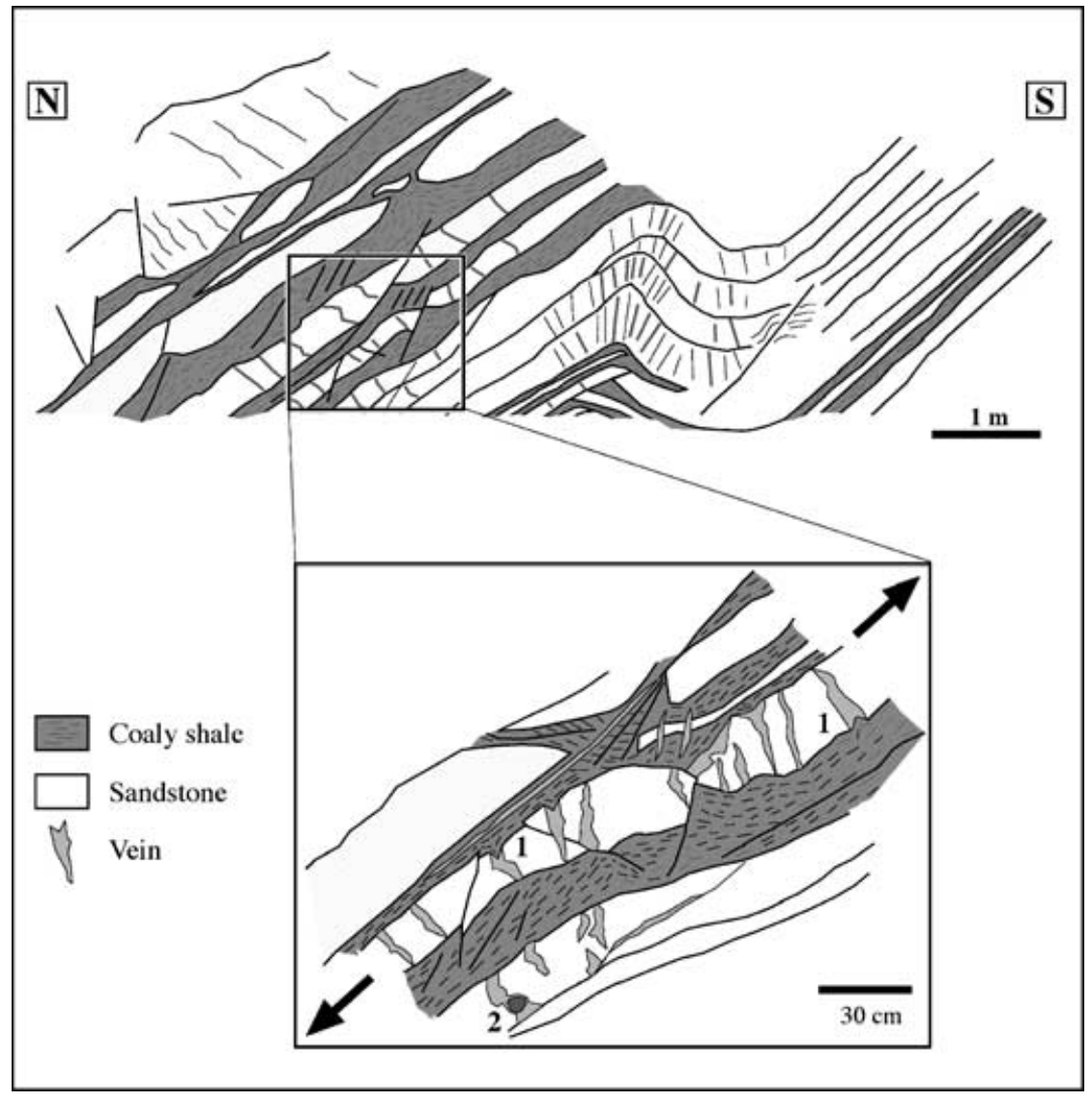

Fig. 3. Outcrop F situated south of the hinge zone of the Llombera Syncline, Bienvenidas Fm (see Fig. 2 and Table 1). This parasitic antiform illustrates the type and scale of the deformation structures present in the coalfield. Quartz-carbonate veins occur in extensional fractures, synchronous with folding, in the upper limb and in the hinge zone. A closer view of the upper thinned limb (arrows indicate the direction of extension) shows that the veins are mostly restricted to the extended sandstone beds and are generally perpendicular to the bedding, with the adjacent coaly shales moving into some of the fractures (1). Occasionally, large pyrite and chalcopyrite crystals have grown along them (2).
$6 \mathrm{~km}$ across. The preserved 1500 -m-thick basin fill consists of a clastic continental sequence (Fig. 2), which was discordantly deposited over older and deformed Palaeozoic rocks during the latter stages of the Variscan Orogeny (Stephanian B, 298-294 Ma). Subsidence was controlled by transtensional movements along the strike-slip fault zone of Sabero-Gordón and was accompanied by igneous activity (Wagner 1971; Méndez Cecilia 1985; Villegas 1996).

The metamorphic grade of these sedimentary rocks, determined by illite crystallinity (IC), ranges from high diagenetic grade to local upper anchizonal conditions (Galán et al. 1978; Frings 2002), which is generally higher than the diagenetic conditions of the surrounding Palaeozoic sequence (García López et al. 1999). According to Méndez Cecilia (1985), there exists a general increase in the thermal maturation of the coal seams with stratigraphic depth. Mean vitrinite reflectance values increase from $1.3 \%$ in the Matallana Formation to $2 \%$ in the San Francisco Fm. However, the highest reflectance values (up to 2.6\%) were recorded in the Pastora Formation. Based on this data, a palaeogeothermal gradient of $60-70^{\circ} \mathrm{C} \mathrm{km}^{-1}$ was proposed for the Stephanian basin, similar to other Stephanian coal basins across the Cantabrian Zone. The high coal ranks have been attributed to the circulation of hydrothermal fluids along major deep faults and the relatively uncompacted and uncemented Upper Carboniferous discordant sediments (Colmenero \& Prado 1993).

As a result of late Variscan compressive/transpressive deformation, metre-to-decametre scale thrusts and folds were formed in the CM basin (Figs 2 and 3). In many cases, the coal beds acted as detachment horizons and are strongly sheared, particularly in the coal-rich Pastora Formation. In places the discordant surface between Stephanian and older Palaeozoic rocks also acted as a principal slip plane. The western half of the basin contains three main eastward plunging synclines (cross-section I and II, Fig. 2), with vertical to steeply south-dipping axial planes. These are separated by poorly developed anticlines located along pre-existing, complexly faulted, horst blocks. In the eastern part of the basin, the structure is simpler and the synclines tend to merge into a large synclinorium with shallower dipping limbs (cross-sections III and IV, Fig. 2). The Sabero-Gordón fault was reactivated during the Alpine uplift of the Cantabrian Mountains in Miocene times, and caused renewed deformation of the Stephanian rocks (Alonso et al. 1995; Villegas 1996; Pulgar et al. 1999).

Deformation was locally accompanied by quartz-carbonate mineralisation, particularly in sandstone and conglomerate beds alternated with shales, organic rich pelites and 
coal-bearing strata. Mineralisation occurs within individual sedimentary layers as steeply dipping, bedding-perpendicular fissures, and also as bedding-parallel slickenside surfaces. The opening of $\mathrm{cm}$-wide fissures occurred synchronous with folding and faulting and was associated with the formation of closely spaced joint systems (Fig. 3).

The intrusive rocks of the CM basin are located preferentially within the three basal formations (San Francisco, Pastora and Cascajo-Roguera). They outcrop in the southern flank of the Matallana Syncline, along the hinge zone and the southern flank of the Tabliza anticline and in the NE area of the basin (Fig. 2). Igneous rock has also been encountered in the Stephanian sequence at depth within exploration boreholes (Méndez Cecilia 1985; Villegas 1996). These rocks are dioritic in composition and show microporphyritic textures. The magmatic bodies were intruded at depths of hundreds of meters (subvolcanic) and consist of small sills and dykes ranging from 1 to $15 \mathrm{~m}$ in thickness. Importantly, some diorites are folded and faulted together with the sedimentary rocks. Characteristically, they penetrated along the coal beds, assimilating wall rock and produced metre thick coke aureoles. In these cases, the intrusive bodies were completely altered to a pale coloured assemblage of carbonates, quartz, iron oxides, chlorite, kaolinite and sericite. Hydrothermal quartz is also present within crosscutting cooling joints in some of the more altered intrusive rocks. Where the igneous bodies intrude other lithologies apart from coal, only local effects on the clay minerals and illite crystallinity indices are registered (Villegas 1996; Frings 2002). The magmatic rocks of the CM basin have mineralogical and chemical affinities with igneous rocks located in other strike-slip related Stephanian coal fields of the Cantabrian Zone, for example the Sabero coal basin (Knight 1983). Although these rocks have not yet been dated, associated magmatic activity and ore deposits within the Cantabrian Zone are of Permian age, ranging from 293 to $262 \mathrm{Ma}$. (Corretgé \& Suárez 1990; Crespo et al. 2000; and references within).

\section{ANALYTICAL METHODS}

\section{Microthermometry}

Fluid inclusions were studied in $100-120-\mu \mathrm{m}$ double polished thick sections prepared from orientated cuts of the vein material. Microthermometric measurements were made using either a Linkam TH600 (Heidelberg) or a Linkam MDS 600 (Leoben) stage. Calibration was performed using synthetic $\left(\mathrm{H}_{2} \mathrm{O}-\mathrm{CO}_{2}\right)$ fluid inclusions, supplied by SYNFLINC, at $-56.6,0.0,+9.9$ and $+374.0^{\circ} \mathrm{C}$, and the melting of $\mathrm{AgNO}_{3}$ at $210^{\circ} \mathrm{C}$. The heating rate used was $5^{\circ} \mathrm{C} \mathrm{min}{ }^{-1}$, and as homogenisation approached, the rate was reduced down to $2-1^{\circ} \mathrm{C} \mathrm{min}^{-1}$. The accuracy of the data is approximately $\pm 0.4^{\circ} \mathrm{C}$ below $-60^{\circ} \mathrm{C}, \pm 0.3^{\circ} \mathrm{C}$ between -60 to $-30^{\circ} \mathrm{C}$ and $\pm 2.5^{\circ} \mathrm{C}$ in the range of $30-220^{\circ} \mathrm{C}$.

\section{Raman microspectrometry}

Gas, liquid and solid phases in fluid inclusions were analysed by a Raman microprobe LABRAM HR-800 at Leoben. Two different wavelengths for the excitation laser radiation were used: $632.8 \mathrm{~nm}$ (red laser) for measurements on calcite and $532.2 \mathrm{~nm}$ (green laser) for quartz. The less energetic red laser source is used to avoid fluorescence in calcite, and because the penetration depth of the red laser is smaller, only fluid inclusions close to the surface can be analysed. Mol fractions of gas species in the inclusion's vapour phase were calculated using a formula derived from Placzek's polarizability theory (Dubessy et al. 1989; Burke 2001). The instrument efficiency number was taken as unity for all components.

\section{Combined Raman and microthermometry}

Accurate identification of ice, salt hydrates (e.g. hydrohalite) and clathrate crystals, formed in fluid inclusions during cooling runs (down to $-196^{\circ} \mathrm{C}$ ), was achieved following the method described by Dubessy et al. (1982), Samson \& Walker (2000) and Bakker (2001a). A Linkam stage (TMS 93) was attached to the Raman microprobe. Recognition of the types of salt hydrates allows determination of the components dissolved in undersaturated fluid inclusions. This method also enables accurate estimation of the true melting temperatures of phases that are difficult to establish, for example, eutectic melting temperatures.

\section{Computer programs and thermodynamic calculations}

Bulk composition and density of fluid inclusions were calculated using the computer packages CLATHRATES (Bakker 1997), including the programs ICE and CURVES, and FLUIDS (Bakker 2001b), incorporating AQSOl, AQSO2, BULK and ISOC. Volume fractions of vapour bubbles were estimated from video images by measuring area percentages. For measurements involving clathrate melting temperatures, the program ICE and CURves were used. The equation of state from Duan et al. $(1992 \mathrm{a}, \mathrm{b})$ was applied to calculate the fugacities of $\mathrm{CH}_{4}$ and $\mathrm{CO}_{2}$ at clathrate melting temperatures. The Q1 point for several gas compositions and the low density of a vapour-like $\mathrm{CH}_{4}$-rich gas mixture were calculated with CuRves. The programs AQSOl and AQSO2 were used to calculate salinities in binary $\mathrm{H}_{2} \mathrm{O}-\mathrm{NaCl}$ systems (Bodnar 1993) and ternary $\mathrm{H}_{2} \mathrm{O}-\mathrm{NaCl}-\mathrm{CaCl}_{2}$ systems (Naden 1996), respectively. Bulk fluid properties of individual fluid inclusions were calculated using the program BULK. For the pure $\mathrm{H}_{2} \mathrm{O}$ system the equations of Haar et al. (1984) and Wagner \& Pruss (1993) have been adopted, and for homogenisation of mixtures of $\mathrm{CO}_{2}$ $\mathrm{CH}_{4}$, the model of Thiery et al. (1994) was applied, which combines the equations of state according to Soave (1972) and Lee \& Kesler (1975). In complex $\mathrm{H}_{2} \mathrm{O}-\mathrm{CH}_{4}-\mathrm{CO}_{2}-$ $\mathrm{NaCl}$ mixtures, the Henry constant according to Rettich 
et al. (1981) and Carroll et al. (1991) was used to calculate $\mathrm{CH}_{4}$ and $\mathrm{CO}_{2}$ solubilities, respectively. The Setzmann \& Wagner (1991) equation was adopted for pure $\mathrm{CH}_{4}$ isochore calculations and that of Krumgalz et al. (1996) to calculate the density of electrolyte bearing aqueous solutions.

\section{VEIN MINERALOGY AND TEXTURAL RELATIONSHIPS}

Vein samples were selected from eight localities (A-G) associated with structures occurring in different stratigraphic units throughout the basin (Fig. 2 and Table 1). Oriented samples were collected from structurally controlled syntectonic fissures, related either to folds or faults. Rock sections were cut, when possible, perpendicular to bedding and retaining portions of the wall rock. Typically, veins are located in sandstone layers adjacent to coal seams, and show little variation in mineralogy, irrespective of structural association and stratigraphic position.

\section{Veins in clastic sedimentary rocks}

The mineralisation history of syntectonic carbonate-quartz veins in the clastic rocks is outlined as follows (Fig. 4A,B). After the initial opening of the fissures small amounts of calcite (call) were precipitated, followed by the growth of large equihedral quartz crystals ( $q t z 1)$, up to $10 \mathrm{~cm}$ in size. The call is only preserved as small relics within qtzl crystals (Fig. 4B) in locality A (sample 26). The quartz directly surrounding this calcite shows growth-zones that parallel their contacts. During and after the last stages of $q t z l$ growth, a ferroan saddle dolomite was precipitated (dolm), which filled remaining voids. Some qtzl crystals have growth zones delimited by trails of small dolomite crystals. Following early mineralisation, both vein and wall rock suffered brittle deformation, with brecciation of host rock and fracturing of detrital grains. Large vein $q t z l$ crystals were microcracked and sometimes detached from the vein walls (Fig. 5). Following brittle deformation a blocky clouded calcite (cal2) precipitated, de-dolomitizing and almost totally replacing dolm, of which only tiny entrapped fragments remain, partly trapped in fluid inclusions within cal2. Cal2 is the most voluminous phase in many veins and contains abundant deformation-induced twins and interpenetrated grain borders. Kaolinite is present in many fault-related veins as an alteration product of the host rock and vein minerals. It is particularly abundant along cal2-host rock contact surfaces and fissure walls, within pore spaces between vein minerals and as halos around entrapped host rock fragments. Minor pyrite and chalcopyrite are also present as disseminated single crystals around cal2 crystals. A third calcite type, cal3, has been recognised within small veins cutting the host rock and the whole vein assemblage. These crystals are only weakly twinned and virtually inclusion-free. 


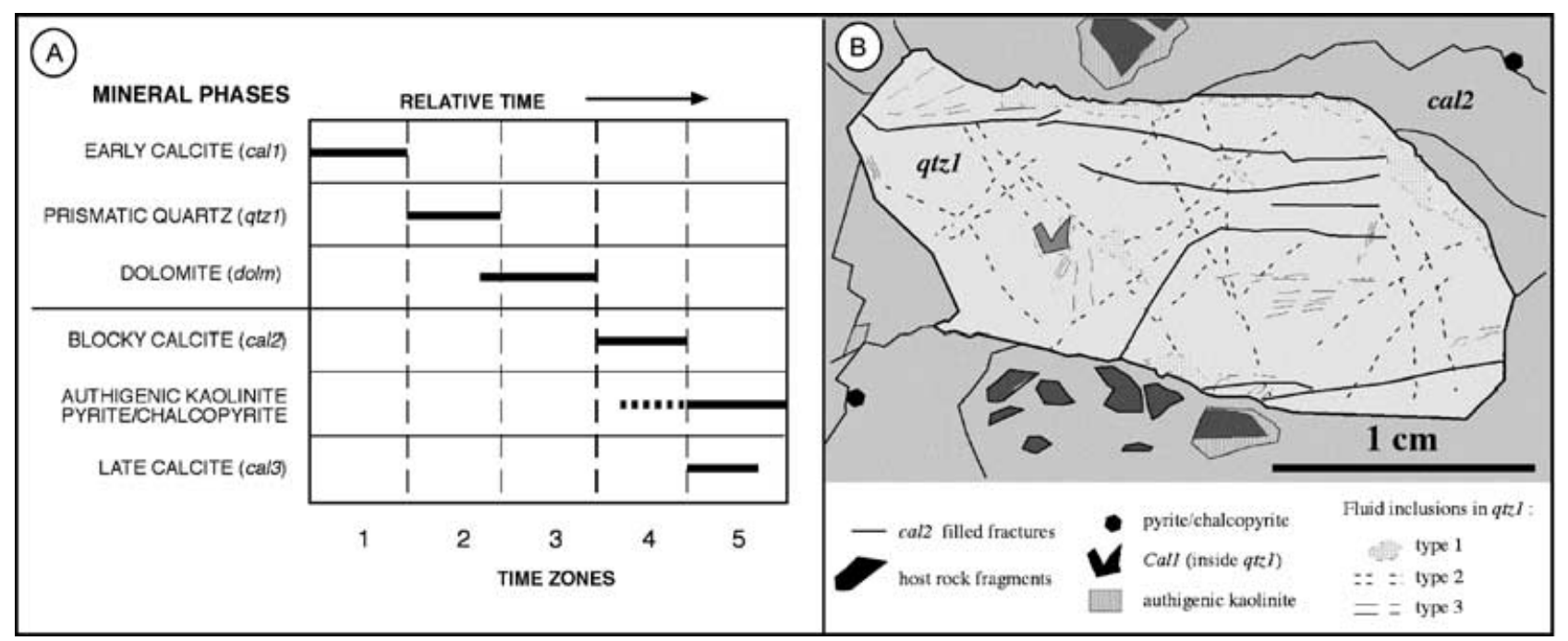

Fig. 4. (A) Table showing the sequence of mineral growth described in the text for the veins in the clastic rocks of the CM basin. (B) Sketch from part of a thin section showing the textural relations of the vein minerals and fluid inclusion assemblages in qtz1.

The absence of fibrous crystals indicates that vein filling occurred within open fissures, with no strain increments or syn-growth deformation (Wilson 1994). Initial crystallisation of $q t z 1$ took place within fluid-filled cavities in a relatively stress-free environment, enabling formation of euhedral prismatic crystals by free face growth that displaced the fluid. The resultant open texture, with large variations in dihedral

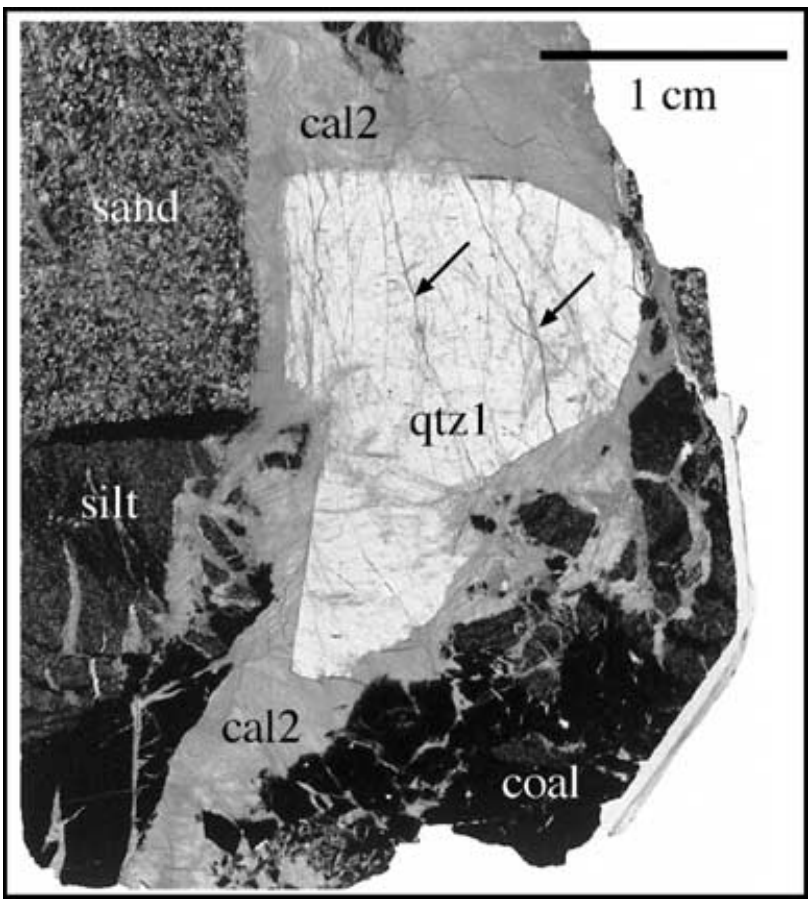

Fig. 5. Photomicrograph of a double polished section ( $100 \mu \mathrm{m}$ thick) from a fault related vein. Sample 26, locality B. Mineralisation (qtz1, and cal2, referring to quartz and calcite, respectively) and deformation features are illustrated. Arrows point to calcite filled cracks (ca/2) in qtz1, sand, sandstone; silt, siltstone.

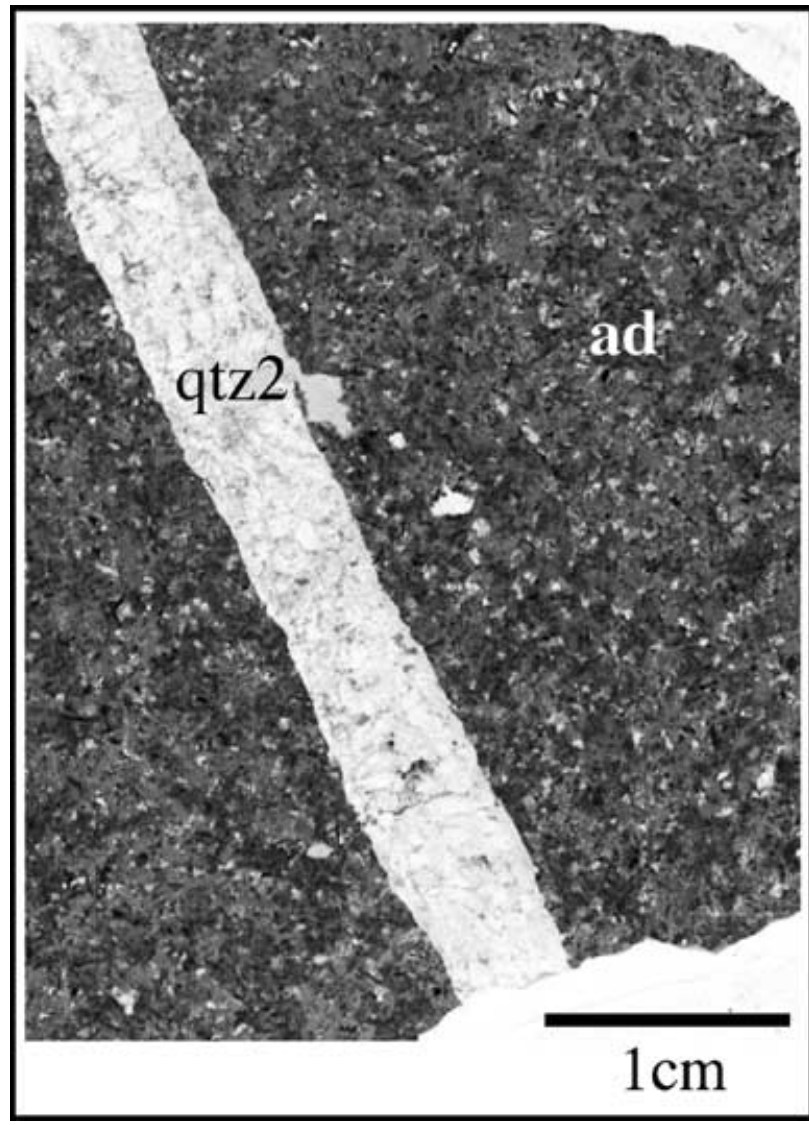

Fig. 6. Photomicrograph of a double polished section ( $100 \mu \mathrm{m}$ thick) from a regular quartz vein (qtz2) in a completely altered igneous rock (ad). Sample 51, locality F. The vein contains about 10 vol. \% of kaolinite. 
angles, allowed passage of further fluids, facilitating fracture reactivation and mineral precipitation within the veins. The mobilisation of material from the overlying and/or underlying shales (also coal) into the veins (Fig. 3), also confirms the existence of open fractures.

Some fragments of wall rock sandstone remain attached to euhedral $q t z 1$ and both show microcracking and mobilisation within the veins. The $q t z l$ contact surfaces with the host rock fragments are irregular and closely follow the boundaries of sand grains. The fact that fracturing followed grain surfaces rather than breaking through individual grains suggest the sands were only weakly cemented at this stage (Fisher \& Byrne 1990). This is in contrast to cal2 crystallisation that follows cracks in detrital grains, producing sharp contact surface between the calcite and the host rock.

\section{Veins in diorites}

Minor hydrothermal quartz $(q t z 2)$ is found in most altered igneous rocks that have intruded through coal beds. The $q t z 2$ is present as (millimeter to centimeter wide) veins in-filling cross-cutting joints (Fig. 6), as cavity-filling nodules that resemble vesicles, and within small pores in the altered diorites. The mineralised joints do not propagate into the adjacent sediments, but they do occur in igneous rocks that appear otherwise undeformed. The $q t z 2$ crystals within veins are subhedral to anhedral (many elongated), have a chaotic orientation, and coarsen towards the centre of the fractures. In the nodules the mineral fabric is inequigranular and interlobate. These features indicate that $q t z 2$ formed as a product of alteration late in the geothermal cycle. As in the previously described veins, late stage kaolinite is abundant in the vertical quartz fissures, filling pores and cracks along qtz2 crystal boundaries.

\section{FLUID INCLUSIONS IN VEINS FROM THE CLASTIC SEDIMENTARY ROCKS}

At least six types of fluid inclusion assemblages are recognised within the three cement generations of the syntectonic

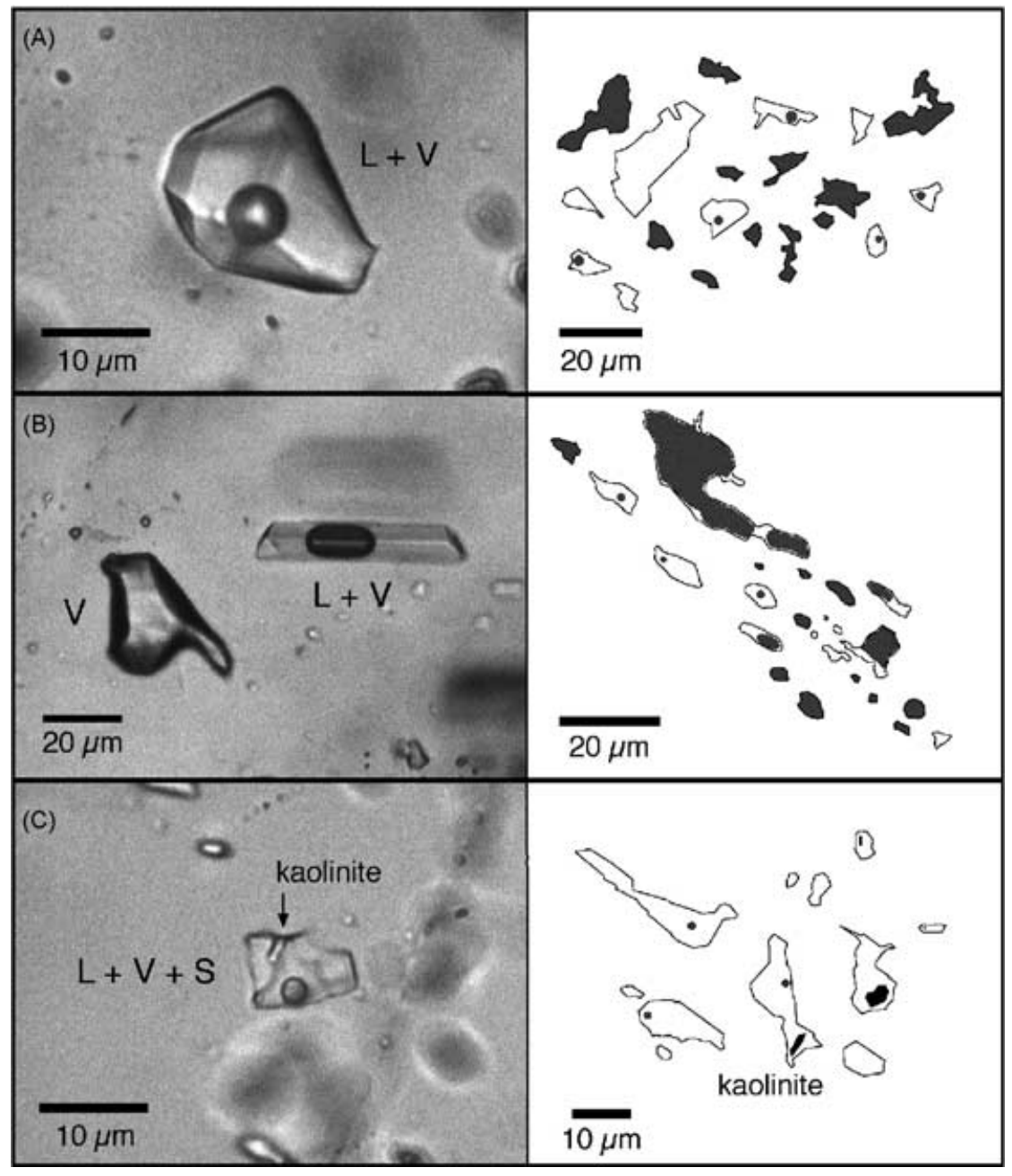

Fig. 7. Photomicrographs and assemblage sketches of fluid inclusions of (A) type 1, (B) type 2 and (C) type 3 in qtz1. Note the variation of aqueous and vapour phase proportions in type 1 and 2 assemblages, indicative of heterogeneous trapping. 
quartz-carbonate veins (Fig. 4B): one in call, three in qtzl, and another two in cal2. The characteristics of these inclusions are outlined as follows, in order of formation (see Figs 7-10 and Table 2). A complete database of the microthermometry and Raman microspectrometry results is included in Supplementary Material.
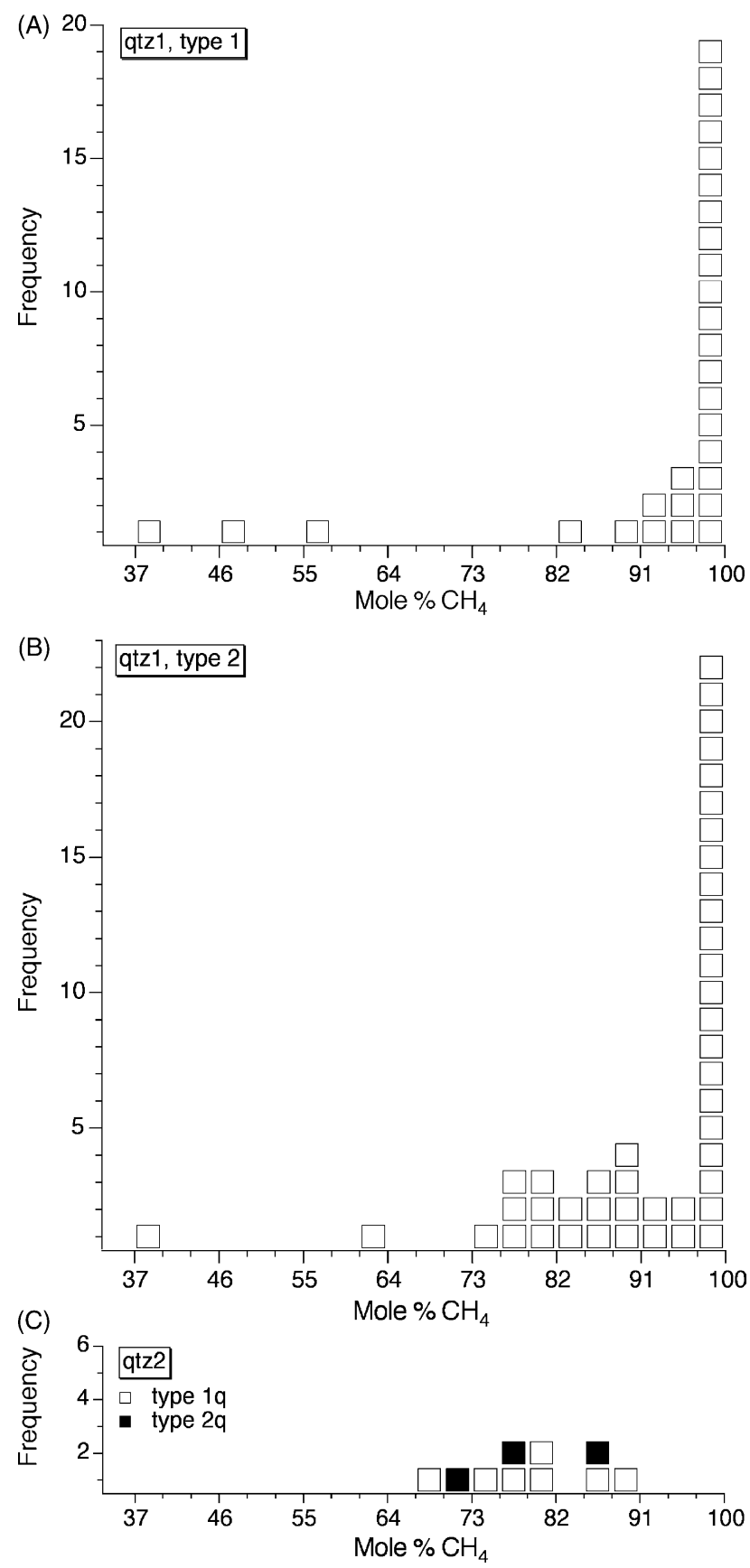

Fig. 8. Histograms illustrating the composition of the $\mathrm{CH}_{4}$ dominated vapour phase, expressed as mol percentage, for inclusions in qtz1 ( $\mathrm{A}$ and $\mathrm{B}$ ) and qtz2 (C). The drop in mol percentage $\mathrm{CH}_{4}$ from type 1 to type $1 \mathrm{q}$ and $2 \mathrm{q}$ inclusions denotes a progressive increase in $\mathrm{CO}_{2}$ content.

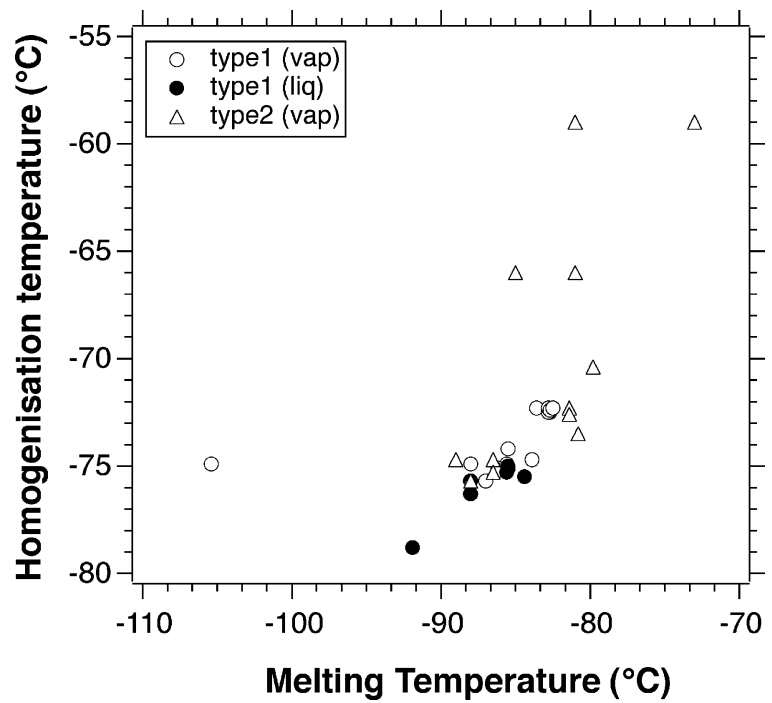

Fig. 9. Plot of melting vs. homogenisation temperatures of the vapour phase for vapour-rich inclusions in qtz1. The shift from type 1 to type 2 inclusions towards higher melting and homogenisation temperatures of the $\mathrm{CH}_{4}-\mathrm{CO}_{2}$ gas mixture indicates progressive enrichment in $\mathrm{CO}_{2}$ and an increase in molar volume, respectively (see Table 3 ). vap $=$ homogenisation into the vapour phase; liq = homogenisation into the liquid phase.

\section{Cal1 inclusions}

This phase contains mainly flat, small $(1-5 \mu \mathrm{m})$ all-liquid aqueous inclusions. A few inclusions contain $<5$ vol.\% vapour $\left(T_{\mathrm{h}}=76-89^{\circ} \mathrm{C}\right.$ ). Pure water (ice melts at $0^{\circ} \mathrm{C}$ ) is the only component identified. The molar volume varies between 18 (all liquid) and $18.65 \mathrm{~cm}^{3} \mathrm{~mol}^{-1}$.

\section{Qtz1 inclusions}

The three types of inclusion assemblages in qtzl are distinguished by distribution within the crystals (Fig. 4B) and by filling degree. Type 1 inclusion assemblages are located within growth zones of the quartz. Inclusions are typically large (up to $10 \mathrm{sec} \mu \mathrm{m}^{-1}$ ) and vapour-dominated (Fig. 7A). Generally they are irregularly shaped, but in some assemblages negative crystal shapes occur. Type 2 inclusions (Fig. 7B) are distributed along crosscutting trails and as small clusters within the quartz crystals (Fig. 4B). Shapes are semi-regular to highly irregular, with sizes ranging up to $50 \mu \mathrm{m}$. Both type 1 and 2 inclusion assemblages show a wide range of filling degrees, probably caused by heterogeneous trapping. The fluid compositions also have strong similarities (Table 2, Fig. 8A,B). The vapour phase is composed mostly of $\mathrm{CH}_{4}, \mathrm{CO}_{2}$ (slightly enriched in type 2 inclusions) with traces of $\mathrm{C}_{2} \mathrm{H}_{6}, \mathrm{C}_{3} \mathrm{H}_{8}$ and $\mathrm{C}_{2} \mathrm{H}_{4}$. Melting temperatures of the $\mathrm{CH}_{4}$-rich gas mixture, between -90 and $-80^{\circ} \mathrm{C}$ (Fig. 9), indicate $\mathrm{CO}_{2}$ mol fractions up to 0.10 . Calculated molar volumes of vapour-rich inclusions range from 69 to $231.59 \mathrm{~cm}^{3} \mathrm{~mol}^{-1}$ for type 1 inclusions, and from 123.68 to $541.09 \mathrm{~cm}^{3} \mathrm{~mol}^{-1}$ for type 


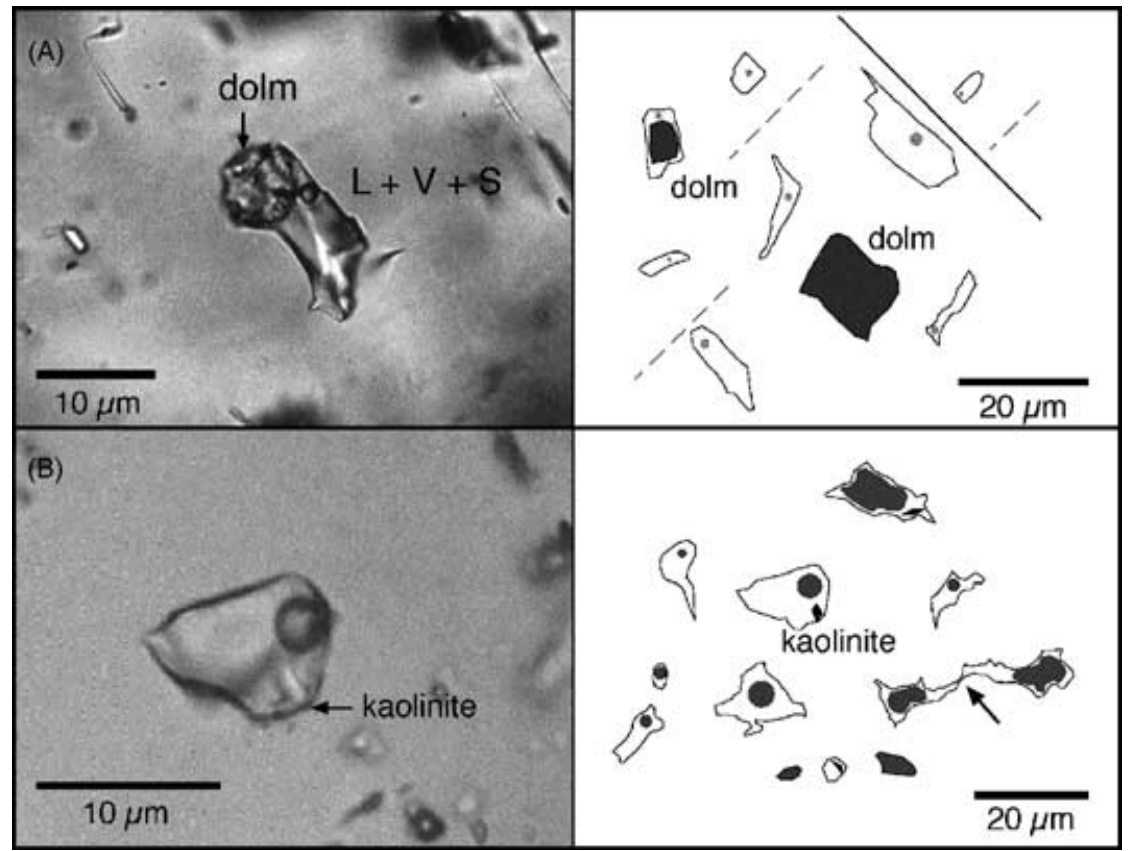

Fig. 10. (A) Photomicrograph and assemblage sketch of type 1c inclusions in cal2. Entrapped dolomite fragments are observed in several aqueous-rich inclusions, providing evidence for dedolomitisation during calcite precipitation. (B) The same for type $1 \mathrm{q}$ inclusions in $q$ tz2. The photo shows one of the numerous inclusions that have entrapped fragments of kaolinite. The sketch of an inclusion cluster provides evidence for heterogeneous trapping of two immiscible fluids and for necking down (see arrow).
2 inclusions (Table 3 ). In many gas-rich inclusions, thin water films wetting the inclusion walls were detected by Raman microspectrometry. The aqueous inclusions have melting temperatures above $-4^{\circ} \mathrm{C}$ and the salinity varies between 2.9 and $5.9 \mathrm{wt} \% \mathrm{NaCl}$ (Table 3 ). $T_{\mathrm{h}}$ values range from 73 to $110^{\circ} \mathrm{C}$ for type 1 , whereas they are slightly higher for type
2 inclusions, from 87 to $129^{\circ} \mathrm{C}$. Using available clathrate and ice melting temperatures, in addition to volume fraction estimates and Raman data, bulk fluid densities between 19.2 and $33.5 \mathrm{~cm}^{3} \mathrm{~mol}^{-1}$ were calculated for type 2 aqueous inclusions (Table 3). Locally, accidentally entrapped fragments of $\mathrm{Mg}$ rich and 'normal' calcite are identified. Many inclusions of

Table 2 Summary of microthermometry and Raman results for five fluid inclusion types in vein minerals of the Ciñera-Matallana basin.

\begin{tabular}{|c|c|c|c|c|c|}
\hline & \multicolumn{3}{|l|}{ qtz1 } & \multirow[b]{2}{*}{ cal2 type $1 \mathrm{c}$} & \multirow{2}{*}{$\begin{array}{l}\text { qtz2 } \\
\text { type } 1 q-2 q\end{array}$} \\
\hline & type 1 & type 2 & type 3 & & \\
\hline Number & 67 & 91 & 83 & 83 & 26 \\
\hline Liquid & $0-100$ & $0-100$ & $95-100$ & $90-100$ & 18-92 \\
\hline$T_{\mathrm{h}}(\mathrm{aq})$ & $73 / 110(110)$ & $87 / 129(120)$ & $40 / 98(55)$ & 60/137 (70) & $150 / 296$ \\
\hline$T_{\mathrm{m}}$ (ice) & $-3.5 /-1.0(-1)$ & $-3.9 / 0.0(-1)$ & $-41.0 /-7.2(-40)$ & $-36 /-4.9(-18)$ & $-2.4 / 0.0(-2)$ \\
\hline$T_{\mathrm{m}}$ (cla) & - & $-3.0 /+12.1$ & $-30.0 /-25.0$ & - & $-5.2 /+16.2$ \\
\hline$T_{\mathrm{m}}(\mathrm{hh})$ & - & - & $-47.0 /-1.2$ & $-27.0 /-21.3$ & - \\
\hline$T_{\mathrm{m}}$ (us) & - & - & $-7.2 /-6.0$ & $-35.8 /-30.2$ & - \\
\hline$T_{\mathrm{m}}(\mathrm{car})$ & $-105.4 /-82.5(-83)$ & $-89.0 /-73.0(-81)$ & - & - & - \\
\hline$T_{\mathrm{h}}(\mathrm{car})$ & $-78.8 /-72.3(-75)$ & $-76.8 /-59.0(-75)$ & - & - & - \\
\hline \multicolumn{6}{|l|}{ Raman } \\
\hline $\mathrm{CH}_{4}$ & $0.24-1.00(1)$ & $0.40-1.00(1)$ & $0.96-1.00(1)$ & 1.00 & $0.78-0.89$ \\
\hline $\mathrm{CO}_{2}$ & $0.00-0.76(0)$ & $0.00-0.60(0)$ & $0.00-0.04(0)$ & - & $0.11-0.28$ \\
\hline $\mathrm{C}_{2} \mathrm{H}_{6}$ & $0.00-0.02(0)$ & $0.00-0.03(0)$ & - & - & - \\
\hline $\mathrm{C}_{3} \mathrm{H}_{8}$ & $0.00-0.01(0)$ & minor & - & - & - \\
\hline $\mathrm{C}_{2} \mathrm{H}_{4}$ & minor & minor & - & - & - \\
\hline \multirow[t]{2}{*}{ Raman low $T$} & \multirow[t]{2}{*}{$\mathrm{H}_{2} \mathrm{O}$ (ice + liq) } & \multirow[t]{2}{*}{$\mathrm{H}_{2} \mathrm{O}$ (ice + liq) } & $\mathrm{H}_{2} \mathrm{O}$ (ice + liq) & $\mathrm{H}_{2} \mathrm{O}$ (ice + liq), & \multirow{2}{*}{$\mathrm{H}_{2} \mathrm{O}$ (ice + liq) } \\
\hline & & & Hydrohalite & Hydrohalite & \\
\hline Trapped minerals & Mg-calcite calcite & Mg-calcite calcite & Kaolinite & Dolomite & Kaolinite \\
\hline
\end{tabular}

All temperature results are given as ranges in ${ }^{\circ} \mathrm{C}$ (mode in brackets).

Number $=$ total number of inclusions measured. Liquid $=$ volume percentage of the aqueous phase (filling degree). $T_{\mathrm{h}}$ (aq) $=$ total homogenisation of aqueous inclusions, always into the liquid phase, only measured for inclusions with a liquid volume percentage $<100 . T_{\mathrm{m}}=$ final melting temperature. $\mathrm{cl}=\mathrm{clathrate}$; liq $=$ liquid; $\mathrm{hh}=$ hydrohalite; us $=$ unidentified salt-hydrate phase. For gas-rich inclusions: $T_{\mathrm{h}}$ (car) $=$ homogenisation temperature of the $\mathrm{CH}_{4}-$ rich carbonic gas mixture; $T_{\mathrm{m}}$ (car) = melting temperature of gas-mixture. Raman = molar fractions of detected gas phases (mode in brackets). Raman low $\mathrm{T}=$ phases detected at temperatures below $0{ }^{\circ} \mathrm{C}$. 
Table 3 Calculated compositions, bulk molar volumes $\left(V_{m}\right)$, eq. wt $\% \mathrm{NaCl}$ and eq. wt $\% \mathrm{CaCl}_{2}$ of individual fluid inclusions in qtz1, cal2 and qtz2. $\dagger$

\begin{tabular}{|c|c|c|c|c|c|c|c|c|c|c|}
\hline & \multirow[b]{2}{*}{ Inclusion Nr. } & \multicolumn{6}{|c|}{ Mol fractions } & \multirow[b]{2}{*}{$V_{m}\left(\mathrm{~cm}^{3} \mathrm{~mol}^{-1}\right)$} & \multirow[b]{2}{*}{$\mathrm{NaCl}(w t \%)$} & \multirow[b]{2}{*}{$\mathrm{CaCl}_{2}$ (wt\%) } \\
\hline & & $\mathrm{H}_{2} \mathrm{O}$ & $\mathrm{CH}_{4}$ & $\mathrm{CO}_{2}$ & $\mathrm{Na}^{+}$ & $\mathrm{Ca}^{2+}$ & $\mathrm{Cl}^{-}$ & & & \\
\hline \multirow[t]{32}{*}{ qtz1 } & type 1 (vap) & & & & & & & & & \\
\hline & $28.1-5$ & - & 0.91 & 0.09 & - & - & - & 169.4 & - & - \\
\hline & 28/1-9\# & - & 0.95 & 0.05 & - & - & - & 80.0 & - & - \\
\hline & 28/1-16\# & - & 0.93 & 0.07 & - & - & - & 72.0 & - & - \\
\hline & 28/1-23\# & - & 0.92 & 0.08 & - & - & - & 69.0 & - & - \\
\hline & $42 / 1-1$ & - & 0.98 & 0.02 & - & - & - & 150.4 & - & - \\
\hline & $42 / 1-2$ & - & 0.98 & 0.02 & - & - & - & 231.6 & - & - \\
\hline & type 2 (aq) & & & & & & & & & \\
\hline & $26 / 2-36 *$ & 0.9799 & 0.0021 & - & 0.0090 & - & 0.0090 & 19.2 & 2.90 & - \\
\hline & $26 / 2-40 *$ & 0.9461 & 0.0176 & - & 0.0181 & - & 0.0181 & 33.5 & 5.86 & - \\
\hline & $31 / 2-7$ & 0.9622 & 0.0048 & 0.0093 & 0.0119 & - & 0.0119 & 19.8 & 3.85 & - \\
\hline & $31 / 2-8$ & 0.9326 & 0.0328 & 0.0172 & 0.0087 & - & 0.0087 & 25.9 & 2.94 & - \\
\hline & type 2 (vap) & & & & & & & & & \\
\hline & $42 / 2-1$ & - & 0.80 & 0.20 & - & - & - & 461.6 & - & - \\
\hline & $42 / 2-2$ & - & 0.79 & 0.21 & - & - & - & 505.8 & - & - \\
\hline & $42 / 2-3$ & - & 0.84 & 0.16 & - & - & - & 498.5 & - & - \\
\hline & $42 / 2-4 \S$ & - & $0.89(0.87)$ & $0.11(0.13)$ & - & - & - & 291.3 & - & - \\
\hline & $42 / 2-8 \S$ & - & $0.98(0.93)$ & $0.02(0.07)$ & - & - & - & 150.4 & - & - \\
\hline & $42 / 2-9$ & - & 0.89 & 0.11 & - & - & - & 541.1 & - & - \\
\hline & $42 / 2-10$ & - & 0.86 & 0.14 & - & - & - & 244.8 & - & - \\
\hline & $42 / 2-11 \S$ & - & $0.92(0.85)$ & $0.08(0.15)$ & - & - & - & 294.6 & & \\
\hline & $42 / 2-12 \S$ & - & $0.86(0.85)$ & $0.14(0.15)$ & - & - & - & 290.6 & - & - \\
\hline & $42 / 2-13 \S$ & - & $0.94(0.85)$ & $0.06(0.15)$ & - & - & - & 294.6 & & \\
\hline & $42 / 2-14 \S$ & - & $0.92(0.91)$ & $0.08(0.09)$ & - & - & - & 123.7 & - & - \\
\hline & type 3 (aq) & & & & & & & & & \\
\hline & $26 / 3-21$ & 0.8476 & 0.0005 & - & 0.0244 & 0.0344 & 0.0931 & 17.0 & 8.54 & 20 \\
\hline & $26 / 3-22$ & 0.8476 & 0.0006 & - & 0.0383 & 0.0251 & 0.0884 & 17.2 & 12.78 & 15.41 \\
\hline & $26 / 3-23$ & 0.8378 & 0.0004 & - & 0.0541 & 0.0179 & 0.0898 & 17.0 & 17.32 & 11.61 \\
\hline & $26 / 3-24$ & 0.8445 & 0.0005 & - & 0.0446 & 0.0220 & 0.0885 & 17.0 & 14.62 & 13.82 \\
\hline & $42 / 3-1$ & 0.8529 & 0.0006 & - & 0.0053 & 0.0453 & 0.0989 & 17.2 & 1.99 & 24.65 \\
\hline & $42 / 3-2$ & 0.8487 & 0.0005 & - & 0.0046 & 0.0472 & 0.0990 & 16.9 & 1.73 & 25.53 \\
\hline & $42 / 3-13$ & 0.8466 & 0.0005 & - & 0.0047 & 0.0479 & 0.1004 & 16.9 & 1.76 & 25.84 \\
\hline \multirow[t]{6}{*}{$\mathrm{cal} 2$} & type $1 \mathrm{c}$ & & & & & & & & & \\
\hline & $48 / \mathrm{cal} 2-1$ & 0.8477 & 0.0008 & - & 0.0369 & 0.0369 & 0.0886 & 17.3 & 12.40 & 15.83 \\
\hline & 48/cal2-6 & 0.8295 & 0.0006 & - & 0.0350 & 0.0332 & 0.1016 & 17.1 & 12.05 & 19.83 \\
\hline & $48 /$ cal2-9 & 0.8646 & 0.0006 & - & 0.0661 & 0.0008 & 0.0677 & 17.4 & 19.89 & 0.56 \\
\hline & $48 / \mathrm{cal} 2-18$ & 0.8755 & 0.0008 & - & 0.0331 & 0.0191 & 0.0713 & 17.5 & 10.93 & 11.87 \\
\hline & $48 / \mathrm{cal} 2-20$ & 0.8892 & 0.0007 & - & 0.0342 & 0.0138 & 0.0619 & 17.5 & 11.11 & 8.77 \\
\hline \multirow[t]{6}{*}{ qtz2 } & type $1 q$ & & & & & & & & & \\
\hline & $51 / 1 q-1$ & 0.9793 & 0.0029 & 0.0029 & 0.0074 & - & 0.0074 & 22.1 & 2.41 & - \\
\hline & $51 / 1 q-2$ & 0.9899 & 0.0020 & 0.0027 & 0.0027 & - & 0.0027 & 20.4 & 0.88 & - \\
\hline & $\begin{array}{l}51 / 1 q-3 \\
\text { type } 2 q\end{array}$ & 0.9709 & 0.0125 & 0.0050 & 0.0058 & - & 0.0058 & 36.1 & 1.91 & - \\
\hline & $51 / 2 q-2$ & 0.8191 & 0.1245 & 0.0513 & 0.0025 & - & 0.0025 & 34.1 & $1.00^{\$}$ & - \\
\hline & $51 / 2 q-4$ & 0.6708 & 0.2360 & 0.0890 & 0.0021 & - & 0.0021 & 61.5 & $1.00^{\$}$ & - \\
\hline
\end{tabular}

$\dagger$ See text for details.

Type 1 vapour-rich inclusions: \# = molar volume graphically estimated with Fig. 7 in Thiery et al. (1994). Type 2 vapour-rich inclusion: $\S=$ adjusted Raman values of mol fractions (in italics) to obtain a solution at the $\mathrm{CH}_{4}-\mathrm{CO}_{2}$ solvus according to Thiery et al. (1994). ${ }^{*}=$ pure $\mathrm{CH}_{4}$ vapour bubble is assumed, according to Raman data for most of type 2 fluid inclusion in sample 26 . In type 3 fluid inclusions of qtz 1 and type 1 in cal2, $V_{\mathrm{m}}$ were calculated assuming a low density of the $\mathrm{CH}_{4}$-rich vapour bubble, arbitrarily set to $1000 \mathrm{~cm}^{3} \mathrm{~mol}^{-1}$. Type $2 \mathrm{q}$ (qtz2) inclusions: $\$=$ salinity is assumed to be $1.0 \mathrm{wt} \% \mathrm{NaCl}$, which is an average value.

both type 1 and 2 assemblages show textural evidence for re-equilibration.

Type 3 fluid inclusions are secondary in origin and distributed as small limited trails decorating microcracks within the crystals. They crosscut type 1 and 2 inclusion assemblages
(Fig. 4B). The inclusions are smaller in size (generally up to $20 \mu \mathrm{m}$ ) and their shapes tend to be highly irregular and very flat, especially the larger inclusions (Fig. 7C). Commonly these inclusions contain entrapped fragments of kaolinite, identified by its Raman spectrum. The vapour phase, which 
is seldom $>\mathbf{5}$ vol. $\%$ and not present in all inclusions, consists mostly of pure $\mathrm{CH}_{4}$, occasionally with minor amounts of $\mathrm{CO}_{2}$. The aqueous phase contains $\mathrm{NaCl}$ and at least one unknown salt. Hypothetical compositions can be obtained by assuming a quaternary system of $\mathrm{H}_{2} \mathrm{O}-\mathrm{CH}_{4}-\mathrm{CaCl}_{2}-\mathrm{NaCl}$ (Table 3). Total salinity, i.e. the summation of $\mathrm{NaCl}$ and $\mathrm{CaCl}_{2}$, vary between 26.6 and $28.9 \mathrm{wt} \%$, where the weight ratio $\mathrm{NaCl} / \mathrm{CaCl}_{2}$ varies between 0.06 and 0.60 . Total homogenisation temperatures (always into the liquid phase) range from 40 to $98^{\circ} \mathrm{C}$. Calculated bulk molar volumes vary between 16.9 and $17.2 \mathrm{~cm}^{3} \mathrm{~mol}^{-1}$ (Table 3).

\section{Cal2 inclusions}

Inclusions in many samples with cal2 were difficult to study due to the strong deformation and twinning experienced by most of the crystals, especially those in veins associated with faults. The least deformed crystals typically have a core, in which the trapped dolomite fragments are concentrated, and an outer rim of clear calcite. Two inclusion types are distinguishable, whereby the re-equilibration features present in type 1 and 2 inclusions in $q t z 1$ are clearly absent.

Type $1 \mathrm{c}$ inclusions occur mostly as clusters within the core of crystals and are primary in origin (Fig. 10a). They have rounded walls, variable shapes and range from 5 to $20 \mu \mathrm{m}$ in size (locally larger). Inclusions are water-rich, many with a $\mathrm{CH}_{4}$ vapour bubble that never exceeds $10 \%$ of the inclusion volume. The aqueous phase in type $1 \mathrm{c}$ inclusions contains a complex salt mixture ( $\mathrm{NaCl}$-rich) as reflected by the melting temperatures of hydrohalite and other salt hydrates (Table 2). Assuming a quaternary system of $\mathrm{H}_{2} \mathrm{O}-\mathrm{CH}_{4}-\mathrm{CaCl}_{2}-\mathrm{NaCl}$, total salinities, i.e. the summation of $\mathrm{NaCl}$ and $\mathrm{CaCl}_{2}$, vary between 20.5 and 31.9 wt\% (Table 3 ). The total homogenisation temperatures, always into the liquid phase, lie between 62 and $137^{\circ} \mathrm{C}$. Calculated bulk molar volumes vary between 17.1 and $17.5 \mathrm{~cm}^{3} \mathrm{~mol}^{-1}$ (Table 3 ). Some inclusions contain entrapped corroded crystals of dolomite, identified by its Raman spectra.

Type $2 \mathrm{c}$ inclusions are flat, variable in size and show sharp/ square edges. They form trails of secondary inclusions, which lie close to and parallel twin planes. Inclusions are all liquid and the aqueous phase is composed of almost pure water (up to $2.1 \mathrm{wt} \% \mathrm{NaCl}$ ). As a vapour phase is lacking, trapping temperatures are considered to be below $50^{\circ} \mathrm{C}$ (e.g. Goldstein \& Reynolds 1994).

\section{FLUID INCLUSIONS IN VEINS FROM THE DIORITES}

Inclusions in diorite-hosted vein quartz $(q t z 2)$ are distributed in several distinct assemblage types. The first generation consists of inclusions formed in clusters inside single crystals (type lq). Three types of secondary trails crosscut grains, lying at various angles to the vein walls (either perpendicular or oblique). These trails contain inclusions $<2 \mu \mathrm{m}$, which are too small to study. Other inclusions occur in the pore filling quartz (type $2 \mathrm{q}$ ) of the adjacent host rock, and were probably contemporaneous with the clusters inside the vein quartz.

Both type $\mathrm{lq}$ and $2 \mathrm{q}$ have semi-regular to irregular shapes with rounded walls (Fig. 10B), although some are regularly shaped (negative crystal shape). Besides necking down, no other re-equilibration textural features were observed. In all the studied assemblages, inclusions are composed of a liquid and a vapour phase that coexist with highly variable filling degrees, ranging from 0.18 to 0.94 (Table 2 ). This large variation suggests a heterogeneous trapping mechanism for these fluids. Type $2 \mathrm{q}$ inclusions in the pore filling quartz are mainly vapour-rich and have a higher gas content than type lq. The vapour phase is $\mathrm{CH}_{4}$-rich with a higher $\mathrm{CO}_{2}$ content (mol fraction between 0.11 and 0.28 ) than inclusion type 1 and 2 in qtzl (Fig. 8C). The salinity of aqueous type $\mathrm{lq}$ and $2 \mathrm{q}$ inclusions varies between 0 and $2.5 \mathrm{wt} \% \mathrm{NaCl}$ (Table 3 ). Total $T_{\mathrm{h}}$ for type $\mathrm{lq}$ inclusions ranges between 150 and $296^{\circ} \mathrm{C}$. Accidentally entrapped kaolinite is common in many inclusions of this type (Fig. 10B).

\section{RE-EQUILIBRATION TEXTURES}

A wide range of re-equilibration textures can be observed in type 1 and 2 inclusions of $q t z 1$ (Fig. 11). Re-equilibration was, however, not uniform. Both unaffected and highly modified inclusions may occur within the same assemblage. A clear relationship has been observed between inclusion size and the intensity of re-equilibration, whereby larger inclusions are typically more affected. A range of intermediate stages of modification can be recognised in all $q t z l$ samples, including veins that do not contain the later cal2 mineralisation phase (sample 31, Table 1 ). The only exception is sample 27, where only one textural variety was observed (Fig. 11C). The re-equilibration textures identified are summarised as follows.

\section{Scalloped inclusion walls}

This first group of inclusions is characterised by numerous irregularities, sharp edges and re-entrants in the inclusion walls, which suggests dissolution of the adjacent quartz. As a consequence, inclusions become corroded, and adopt chaotic and irregular shapes. Therefore, we use the term scalloped. This texture is predominant in large-sized inclusions irrespective of whether they are liquid or vapour rich (Fig. 11A).

\section{Annular-ring textures}

These exhibit a variety of shapes, which show no relation to whether the inclusion is aqueous or vapour-rich. A common feature is the smooth, round and crystallographically defined inclusion walls. One type is the arch-hook shape, in which the 


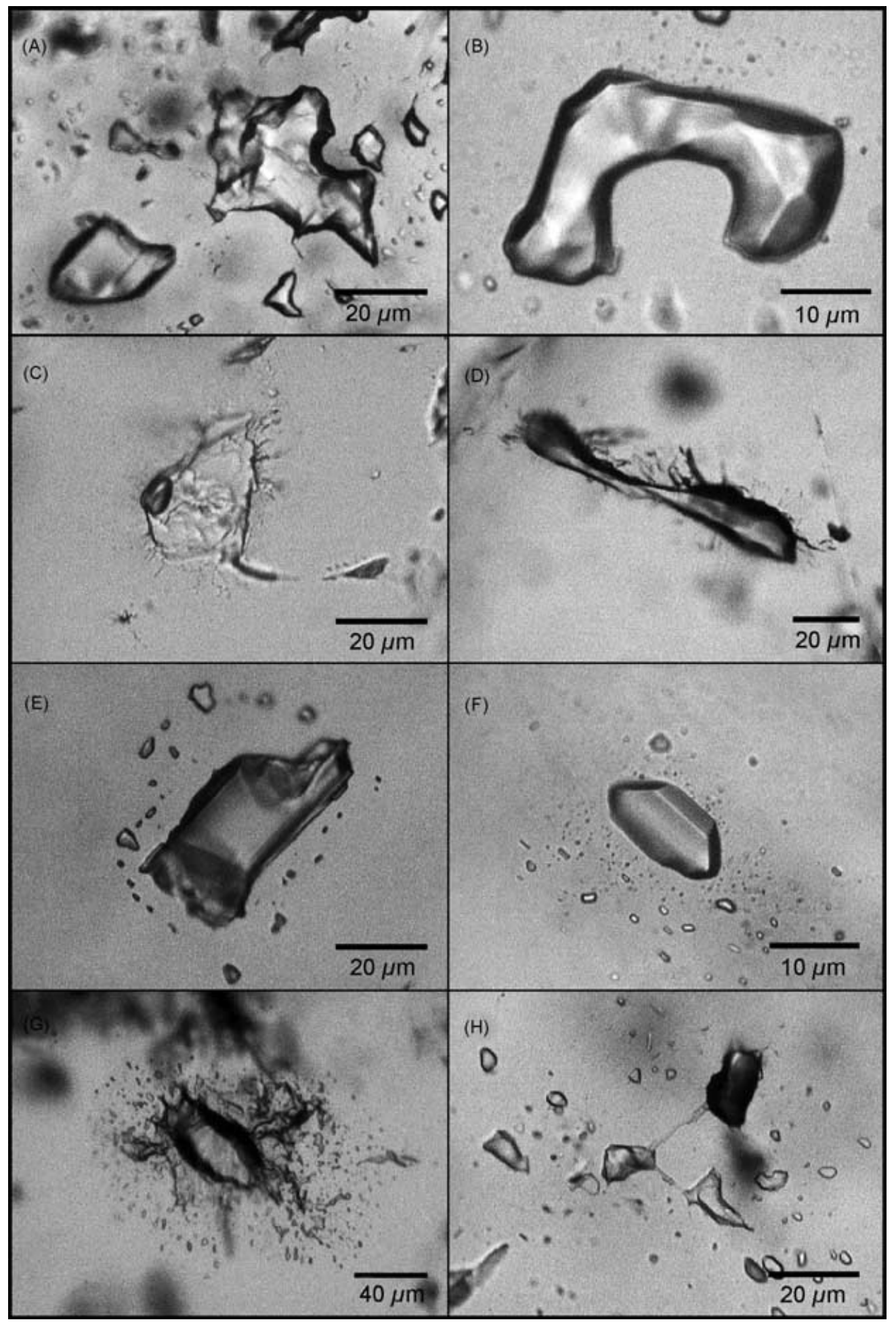

Fig. 11. Photomicrographs summarising the different re-equilibration textures observed in type 1 and 2 fluid inclusions of qtz1 from sample 28 , locality $B$ ( $A$, $F$, $G, H)$; sample 27 , locality $D(C)$; and sample 42 , locality $F(B, D, E)$. See text for further explanation.

ring is not totally closed (Fig. 11B). A second type consists of inclusions with a single, relatively small patch of enclosed crystallised quartz, pillaring the inclusion walls. A rare third type comprises tubular ring-shaped inclusions.

\section{Hairy textures}

These inclusions have numerous microtubes or microfractures, which radiate from the walls to give a hairy appearance. 
This texture occurs in both liquid- and vapour-rich inclusions (Fig. 11C,D). In detail, these tubes have highly irregular forms and very small diameters, and are generally filled with $\mathrm{H}_{2} \mathrm{O}$ (Raman detected). The larger tubes and fractures typically occur around vapour-rich inclusions (Fig. 11D).

\section{Haloes}

Haloes are defined as a group of small daughter inclusions around a regular shaped parent inclusion (Fig. 11E,F). They consist of either planar or three-dimensional arrays of minute inclusions. In our examples, they occur preferentially around vapour-rich inclusions. The daughter inclusions may outline the initial shape of the parent inclusion (Fig. 11E), whereby both daughter and parent have negative crystal shapes and similar compositions. But compositional differences were also observed in parent-daughter combinations (Fig. 11F). Inclusions with semi-irregular wall shapes may also develop such haloes.

\section{Decrepitation clusters}

True decrepitation clusters consist of single planar fractures branching out from the inclusion walls in all directions and completely surround the parent inclusion (Fig. 11G). The fractures have not healed completely, giving a very irregular appearance to the parent inclusion. The numerous minute inclusions formed in the healed part of the fracture are also highly irregular, in contrast to the haloes in Fig. $11(\mathrm{E}, \mathrm{F})$. These clusters show absence of re-crystallised inclusion-free quartz directly adjacent to the parent inclusion, and the fractured haloes are more oval in shape. Such textures are observed around both liquid- and vapour-rich inclusions.

\section{Necking down}

Typical necking-down textures are observed as small tubes of varying geometry that connect larger inclusions (Fig. 11H). Total separation of fluid phases may occur when the connecting tube is sealed, causing formation of all-liquid and -vapour fluid inclusions. In the example shown in Fig. $11(\mathrm{H})$, phase separation has nearly reached completion, as the darker vapour-rich part is connected by a narrow tube to the brighter aqueous-rich part.

\section{DISCUSSION}

\section{The sequence of fluid events}

Following sedimentation in the Ciñera-Matallana basin, an early period of deformation and fracturing took place within a sedimentary pile characterised by anomalously high heat flow and a rapidly maturating rock sequence. Small amounts of calcite (call) crystallised from a temperate, low salinity

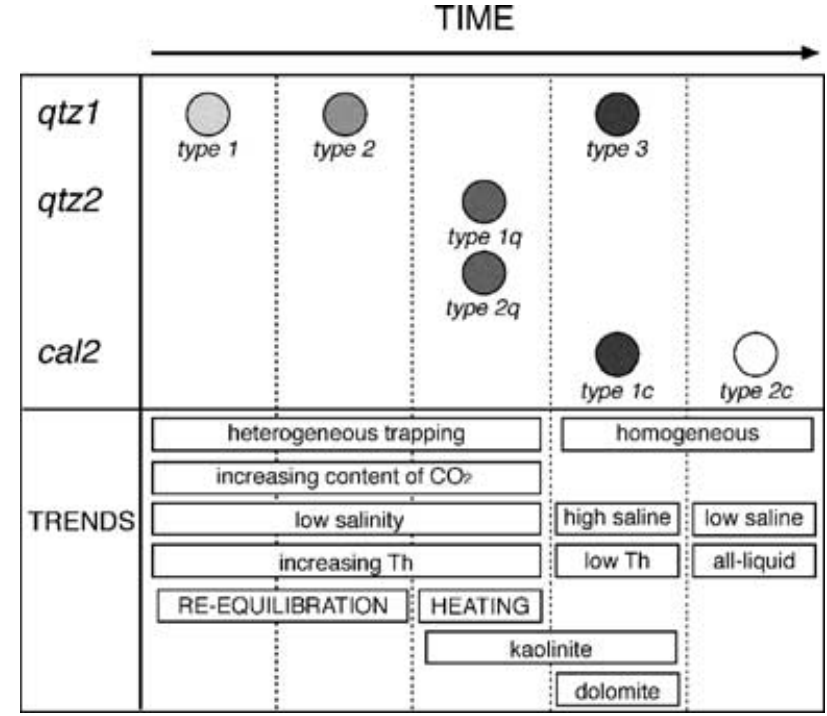

Fig. 12. Schematic diagram illustrating the relations between vein mineralisation ( $q t z 1, q t z 2$ and $c a / 2)$ and fluid inclusion types. Trends indicate mode of trapping (heterogeneous or homogeneous), occurrence of re-equilibration textures, salinities, accidentally trapped minerals (kaolinite and dolomite), $\mathrm{CO}_{2}$ contents, and homogenisation temperatures.

aqueous fluid at shallow depths within open fractures, which also hosted subsequent vein growth. Younger fluid events and their associated characteristics within these rocks are schematically illustrated in Fig. 12. In open fissures, quartz $(q t z l)$ precipitated as large euhedral crystals in the presence of an immiscible fluid mixture, composed of a low salinity aqueous solution and a $\mathrm{CH}_{4}$-rich vapour phase. The fluids responsible for this mineralisation formed by thermal dewatering and maturation of the continental sedimentary rocks, particularly the organic-rich shales and coal seams. Both fluid end-members were trapped heterogeneously in the large quartz crystals as type 1 and 2 fluid inclusions. Type 2 inclusions have progressively higher homogenisation temperatures and $\mathrm{CO}_{2}$ content than type 1 (Table 2 and Fig. 12).In order to estimate the trapping conditions, the solvi for several vapour-rich inclusions in the $\mathrm{H}_{2} \mathrm{O}-\mathrm{CH}_{4}-\mathrm{CO}_{2}-\mathrm{NaCl}$ system were calculated at relative low temperatures. Corresponding pressures were numerically derived using the homogenisation temperatures measured in water-rich end-member inclusions. The fluid pressures at formation conditions were relatively low, ranging from 15 to $56 \mathrm{MPa}$ for type 1 and from 10 to $27 \mathrm{MPa}$ for type 2 (Fig. 13A). The characterisation of the veins as open fissures, their distribution throughout the whole sediment sequence and the low pressures of fluid entrapment, together with the absence of pressure trends with depth, indicate that hydrostatic pressure conditions prevailed during vein formation.

The re-equilibration of only type 1 and 2 inclusions in qtzl marks the onset of a specific event, which occurred at some stage following qtzl crystallisation and before the second 

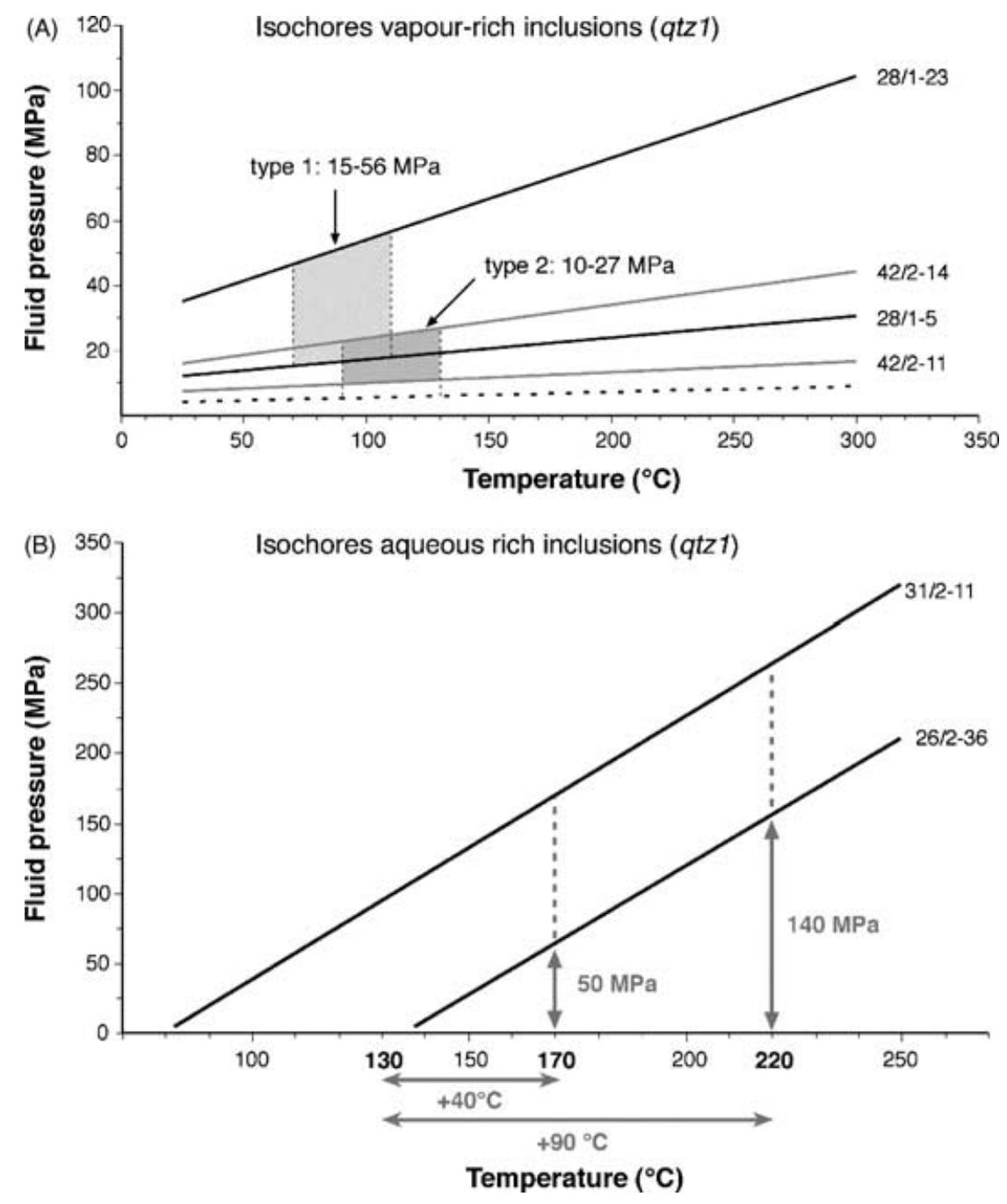

Fig. 13. (A) $P-T$ diagram with four isochores, representing the higher and the lower calculated molar volumes for vapour-rich inclusions of type 1 and 2 in qtz 1 samples 28 and 42, determined using Duan et al. (1992a,b, 1996). The trapping pressures are obtained from the homogenisation temperatures of coexistent, aqueous rich end member inclusions (Table 2). The lower dashed curve indicates the position of the isochores of vapour-rich inclusions with molar volumes above $400 \mathrm{~cm}^{3} \mathrm{~mol}^{-1}$. (B) $P-T$ diagram with isochores for aqueous-rich fluid inclusions in qtz1 representing the lower (31/1-11) and the higher (26/2-36) homogenisation temperatures. Isochores were calculated for pure $\mathrm{H}_{2} \mathrm{O}$ (Haar et al. 1984) as the low concentration of $\mathrm{CH}_{4}$ and $\mathrm{NaCl}$ do not significantly affect their positions. The minimum overpressures documented by these inclusions, at rock temperatures of $170-220^{\circ} \mathrm{C}$, range from 50 to $140 \mathrm{MPa}$. See text for details.

generation of blocky calcite (cal2). Isochore calculations for type 1 and 2 aqueous inclusions in the fissure quartz, qtzl, indicate that in order to reach internal overpressures of about $100 \mathrm{MPa}$ at low confining pressures, the surrounding temperature needs to rise about $50-60^{\circ} \mathrm{C}$ for the water-rich inclusions (Fig. 13B). This overpressure is high enough to decrepitate inclusions larger than $30 \mu \mathrm{m}$ (Bodnar et al. 1989; Lacazette 1990). Over the same temperature interval, vapour-rich inclusions can attain overpressures of only 13$20 \mathrm{MPa}$ (Fig. 13A).

At a late stage of qtzl growth, saddle dolomite (dolm) precipitated, partly enclosed as solid inclusions in $q t z 1$. The formation conditions of the younger, relic dolm are not known, as only small crystals are preserved. Even the largest fluid inclusions $(<2 \mu \mathrm{m})$ in dolm are too small for analysis. Formation temperatures from fluid inclusions in saddle dolomite available from the literature can only be approximated to be above $60-80^{\circ} \mathrm{C}$, with a maximum between 90 and $160^{\circ} \mathrm{C}$ (Spötl \& Pitman 1998). This mineral phase is also typically associated with the input of saline palaeofluids. The overall fluid properties of inclusions in vein-quartz ( $q t z 2)$ in the dioritic bodies are similar to the trends observed in the fluid inclusions of qtzl (Fig. 12). However, homogenisation temperatures and $\mathrm{CO}_{2}$ content reach higher values in type $\mathrm{lq}$ and $2 \mathrm{q}$ fluid inclusions and re-equilibration textures are not observed in inclusions of $q t z 2$. Therefore, it appears that the postmagmatic quartz in diorite represents a mineralisation product formed at high temperatures relative to basin conditions, which may be related to the re-equilibration of inclusions in the fissure quartz of the country rocks ( $q t z 1)$.

Subsequently, brittle reactivation of veins in the clastic rocks caused reopening and microcracking of the large quartz crystals. Calcite (cal2) precipitated at relative low temperatures, around $70-80^{\circ} \mathrm{C}$, from a highly saline fluid, which was trapped as primary inclusions in cal2 (type lc) and as secondary inclusions in qtzl (type 3). Extensive dedolomitisation also took place. This phase, together with the ongoing deformation that followed cal2 formation and the latest calcite (cal3) may have a much later origin than the other minerals present in the veins. 


\section{Conditions and mechanisms of re-equilibration}

The variety of textures observed in qtzl indicates that several mechanisms operated simultaneously during re-equilibration. Some of the previously described experimental re-equilibration textures (especially scalloped and annular-ring structures) have been formed at both internal over- and underpressurised conditions. Variables other than temperature and pressure alone play an important role in the development of re-equilibration textures. Material properties of the host are usually completely ignored. Sterner et al. (1995) suggested that even chemical potentials of fluid components inside the inclusions might play an indirect role, at least in experimental studies.

In principle, two independent processes can change the morphology of individual fluid inclusions:

(1) decrepitation, i.e. sudden change in the total inclusion volume by newly formed microcracks and/or dislocation arrays;

(2) dissolution and precipitation of quartz on the inclusion walls.

In the first mechanism, chemical interaction between fluid and host mineral is excluded and the host mineral is considered as a homogeneous solid medium. A first approach is to consider re-equilibration simply as a brittle mechanical phenomenon, described by physical variables such as pressure, temperature, inclusion shape and volume. In the case of fluid overpressure the inclusion acts as an internally pressurised crack (Lacazette 1990). Fractures will generate and propagate from the inclusion walls if the internal pressure is above the host mineral lattice strength. These fractures tend to be planar and their orientation and intensity is governed by the mineral properties. Nevertheless, crack growth may occur at stress levels below those necessary to exceed lattice strength by mechanisms such as stress corrosion (by water), dissolution, diffusion, ion exchange and microplasticity, all of which may be affected by the chemical environment (e.g. Kronenberg et al. 1986)

Dissolution and precipitation of the host mineral (in this case quartz) is the main mechanism by which fluid inclusions form. Inside inclusions, this process does not cease after a pocket of fluid has been entrapped. Necking-down divides such pockets into multiple inclusions, which tend to obtain negative crystal shapes. This process depends on the solubility of the host mineral in the inclusion fluid, which is enhanced at higher pressures and temperatures. The cause of the subsequent formation of irregular walls is, however, unclear. As observed in internal underpressure experiments, fluid inclusions tend to be redistributed as irregular clouds of many small inclusions. Transport of fluid away from the parent inclusion may occur along microcracks or crystal defects, such as dislocations (Bakker \& Jansen 1994). Some components of that fluid, especially water, may be preferentially lost in response to gradients in pressure and/or water fugacity when re-equilibration takes place. Consequently, quartz moves in the opposite direction, and the parent inclusion will tend to close. In the naturally re-equilibrated inclusions analysed in this study, we have observed that water (Raman detected) is the predominant component in decrepitation clusters, in radial tubes and fractures of the hairy textures, as well as in the haloes exemplified in Fig. 11(F). Additionally, vapourrich re-equilibrated inclusions show lower fluid densities than intact inclusions.

\section{Causes of fluid inclusion re-equilibration in the $\mathrm{CM}$ basin}

Most of the fluid inclusion textures observed in vein quartz ( $q t z l$ ) of the CM basin appear to have formed initially by brittle fracturing of the host mineral, suggesting decrepitation as the main re-equilibration process. The factors that could produce such an effect are discussed as follows.

\section{Mechanical stress}

External mechanical stress applied to the host crystal can produce re-equilibration of inclusions. In most veins single crystals of $q t z l$ are extensively microcracked. However, internal deformation features, such as twinning, pressure shadows, undulose extinction, and the development of subgrain boundaries, are absent. According to our constraints, deformation would have had to have occurred after the formation of type 1 and 2 fluid inclusions (Fig. 12). However, re-equilibration textures are observed in both intensively cracked quartz and in virtually undeformed crystals (e.g. sample 31). Moreover, brittle fracturing at this stage of development would result in refilling of original inclusions with a highly saline fluid (compositional re-equilibration). This feature is locally observed when the microcracks forming type 3 inclusions cut type 1 and 2 assemblages, but the inclusions affected can be clearly differentiated from other re-equilibrated ones. We can therefore exclude external mechanical stresses as the principle cause of re-equilibration.

\section{Decompression}

A decrease in the confining pressure of the host quartz is a feature that may result from fast erosion rates. The original fluid trapping pressures of primary inclusions (and so for the mineral crystallisation) were low for $q t z 1$, and ranged between 10 and $56 \mathrm{MPa}$. A fast uplift of the sequence caused by erosion and/or exhumation would not generate a pressure gradient high enough to induce extensive decrepitation, since a minimum pressure difference of $85 \mathrm{MPa}$ is required in quartz to influence a fluid inclusion as large as $35 \mu \mathrm{m}$ (e.g. Lacazzete 1990). The required pressure difference becomes much higher as the inclusion size decreases. The CM basin is estimated to have reached a maximum thickness of 2500 $\mathrm{m}$ (Villegas 1996), and it was overlain by a thin discordant sequence of Cretaceous cover, with a preserved thickness between 150 and $450 \mathrm{~m}$ in areas nearby (Lobato et al. 
1984; Alonso et al. 1990). Vein samples of qtzl with decrepitated inclusions are reported throughout the stratigraphic sequence of the basin (Pastora to Bienvenidas Formations), and we observed no difference in the intensity and character of the textures in relation to burial depth. These features also indicate that $P-T$ paths that generate fluid underpressure within inclusions (cooling and burial) are not realistic causes of re-equilibration in this setting.

\section{Heating}

Maximum temperatures reached in the sedimentary succession are estimated to have been $170-220^{\circ} \mathrm{C}$, based on the conversion of vitrinite reflectance values with the formula of Barker \& Pawlewicz (1986). Such estimates are also in agreement with local anchizonal grade metamorphism. Although the heating period was, geologically speaking, relatively short, the enhanced rock temperatures were high enough to generate minimum fluid overpressures of 50-140 MPa within the inclusions (Fig. 13B). In such a case, re-equilibration of inclusions in the fissure quartz could be induced.

There are strong grounds for relating peak palaeotemperatures and therefore inclusion decrepitation to the high heat flow associated with Permian igneous activity. Magma temperatures for the intrusive dioritic material are estimated to have been about $800-850^{\circ} \mathrm{C}$ (Méndez-Cecilia 1985). However, the distribution of our data does not allow us to establish the nature of temperature gradients in the vicinity of these igneous intrusions. As a result, we cannot reliably assess whether heat was transmitted locally by conduction through solid rock or by the more widespread advection of hydrothermal fluids through pore spaces and fractures within the sedimentary basin.

\section{CONCLUSIONS}

Fissure mineralisation in clastic rocks of the Ciñera-Matallana coal basin started with minor amounts of calcite (call) and was followed by euhedral quartz (qtzl) formed from a low salinity $\mathrm{H}_{2} \mathrm{O}-\mathrm{CH}_{4}-\mathrm{NaCl}$ fluid mixture heterogeneously trapped at temperatures of $110-120^{\circ} \mathrm{C}$ and pressures between 10 and $56 \mathrm{MPa}$. Progressively higher temperatures are reflected in the formation of quartz (qtz2) in igneous rocks from a similar fluid at $150-290^{\circ} \mathrm{C}$. An increase in $\mathrm{CO}_{2}$ content occurs with this trend, with inclusions in qtz2 having locally up to $20 \mathrm{~mol}$.\% $\mathrm{CO}_{2}$. Subsequently, in the clastic rock fissures, calcite (cal2) crystallised from a highly saline $\mathrm{H}_{2} \mathrm{O}-\mathrm{CH}_{4}-\mathrm{CaCl}_{2}-\mathrm{NaCl}$ homogeneous fluid at lower temperatures $\left(70-80^{\circ} \mathrm{C}\right)$. This late fluid was also entrapped as secondary inclusions in qtzl.

A heating event affecting the entire rock sequence re-equilibrated fluid inclusions in qtzl, before the precipitation of cal2. Re-equilibration textures of inclusions in qtzl show a large variety of modifications, even within single crystals, illustrating the diversity of this process. Progressive grades of re-equilibration can be recognised as scalloped textures, through hairy, annular-ring textures and haloes up to decrepitation clusters.

Internal overpressure due to overheating of host qtzl was the main cause for the development of re-equilibration textures in fluid inclusions. Water was preferentially removed from the parent inclusions during this process. Textural variety (decrepitation clusters are predominant) reflects different states of quartz healing (dissolution and precipitation) within fluid inclusions after the formation of small fractures within a limited area around the inclusions. Many of those textures (ring, hairy, haloes) have been previously reported only for internally underpressurized fluid inclusions.

Thermal decrepitation was caused by an increase in heat flow associated with magmatic activity in the Ciñera-Matallana basin. Although not all re-equilibration textures are exclusive to one re-equilibration path, careful textural and compositional examination of fluid inclusions in natural quartz from diagenetic and very low-grade metamorphic rock sequences, in combination with other geological information, can provide useful information concerning basin thermal history.

\section{ACKNOWLEDGEMENTS}

This work forms part of FA's PhD thesis, funded by the DFG (German Research Foundation), 'Graduiertenkolleg' Program 273 on Fluid Rock Interaction, at the Faculty of Geosciences, University Heidelberg. F.A. thanks C. Brime and F. Àlvarez for their encouragement during the early stages of the project. Special thanks to L. Diamond and all the people of the Mineralogy and Petrology Department in Leoben for their kindness and helpful discussions during the Raman microspectrometry work. M. P. Smith, R. Worden and B. W. D. Yardley are thanked for their critical reviews of the manuscript.

\section{SUPPLEMENTARY MATERIAL}

The following material is available from http://www.blackwellpublishing.com / products / journals / suppmat /gfl/gfl048 / gfl048sm.htm

\section{APPENDIX}

Table Al Raman Laser microprobe spectroscopic analyses of type 1 and type 2 fluid inclusions in $q t z 1$.

Table A2 Microthermometry data and volume fractions at room temperature of type 1 vapour-rich fluid inclusions in qtzl (sample 28).

Table A3 Microthermometry data and volume fractions at room temperature of type 1 aqueous fluid inclusions in $q t z 1$ (sample 31).

Table A4 Microthermometry data and volume fractions at room temperature of type 2 vapour-rich fluid inclusions in qtzl (samples 28 and 42). 
Table A5 Microthermometry data and volume fractions at room temperature of type 2 aqueous fluid inclusions in qtzl (samples 26 and 31).

Table A6 Microthermometry data and volume fractions at room temperature of type 3 aqueous fluid inclusions in $q t z 1$ (samples 26, 31 and 42).

Table A7 Raman laser microprobe spectroscopic analyses of the vapour phase of type 3 fluid inclusions in $q t z 1$.

Table A8 Microthermometry data and volume fractions at room temperature of type lc fluid inclusions in cal2 (samples 26, 42 and 48).

Table A9 Microthermometry data and volume fractions at room temperature of type $1 \mathrm{q}$ and type $2 \mathrm{q}$ fluid inclusions in $q t z 2$ from altered dioritic igneous bodies (sample 51).

Table A10 Raman laser microprobe spectroscopic analyses of the vapour phase of type $1 \mathrm{q}$ and type $2 \mathrm{q}$ fluid inclusions in qtz2 (sample 51).

\section{REFERENCES}

Alonso JL, Pulgar JA, García Ramos JC, Barba P (1995) Tertiary basins and alpine tectonics in the Cantabrian Mountains (NW Spain). In: Tertiary Basins of Spain (eds Friend PF, Dabrio CJ), pp. 214-27. Cambridge University Press, Cambridge.

Alonso JL, Suárez Rodríguez A, Rodríguez Fernandez LR, Farias P, Villegas FJ (1990) Hoja del Mapa Geológico de España E. 1:50:000. no. 103 (LA POLA DE GORDÓN). 2 Serie Magna, ITGE.

Audetat A, Günther D (1999) Mobility and $\mathrm{H}_{2} \mathrm{O}$-loss from fluid inclusions in natural quartz crystals. Contributions to Mineralogy and Petrology, 137, 1-14.

Bakker RJ (1997) Clathrates: computer programs to calculate fluid inclusion $V-X$ properties using clathrate melting temperatures. Computers and Geosciences, 23, 1-18.

Bakker RJ (2001a) Combined Raman Spectroscopy and low temperature Microthermometry. In: XVI ECROFI, European Current Research on Fluid Inclusions, [Abstracts] Porto 2001. (eds Noronha F, Doria A, Guedes A). Faculdade de Ciencias do Porto, Departamiento de Geologia. Memória no. 7, pp. 15-8. University of Porto.

Bakker RJ (2001b) FLUIDS: new software package to handle microthermometric data and to calculate isochores. XVI ECROFI, European Current Research on Fluid Inclusions; Porto 2001 (eds Noronha, F, Doria, A, Guedes, A) Faculdade de Ciencias do Porto, Departamiento de Geologia, Memoria no. 7, pp. 23-5. University do Porto. [Abstracts].

Bakker RJ, Jansen JBH (1990) Preferential water leakage from fluid inclusions by means of mobile dislocations. Nature, 345, 58-60.

Bakker RJ, Jansen JBH (1991) Experimental post-entrapment water loss from synthetic $\mathrm{CO}_{2}-\mathrm{H}_{2} \mathrm{O}$ inclusions in natural quartz. Geochimica et Cosmochimica Acta, 55, 2215-30.

Bakker RJ, Jansen JBH (1994) A mechanism for preferential $\mathrm{H}_{2} \mathrm{O}$ leakage from fluid inclusions in quartz, based on TEM observations. Contributions to Mineralogy and Petrology, 116, 7-20.

Barker CE, Pawlewicz MJ (1986) The correlation of vitrinite reflectance with maximum temperature in humic organic maffer. In: Palaeogeothermics (eds Buntebarth G, Stegena L). Springer, Heidelberg. Lecture Notes in Earth Sciences, 5, 79-93.

Bodnar RJ (1993) Revised equation and table for determining the freezing point depression of $\mathrm{H}_{2} \mathrm{O}-\mathrm{NaCl}$ solutions. Geochimica et Cosmochimica Acta, 57, 683-4.
Bodnar RJ, Bethke PM (1984) Systematics of stretching of fluid inclusions. Part I. Fluorite and sphalerite at 1 atmosphere confining pressure. Economic Geology and the Bulletin of the Society of Economic Geologists, 79, 141-61.

Bodnar RJ, Binns PR, Hall DL (1989) Synthetic fluid inclusions. Part VI. Quantitative evaluation of the decrepitation behaviour of fluid inclusions in quartz at one atmosphere confining pressure. Journal of Metamorphic Geology, 7, 229-42.

Boullier AM, France-Lanord C, Dubessy J, Adamy J, Champenois M (1991) Linked fluid and tectonic evolution in the High Himalayan Mountains (Nepal). Contributions to Mineralogy and Petrology, 107, 358-72.

Burke EAJ (2001) Raman microspectrometry of fluid inclusions. Lithos, 55, 139-58.

Burrus RC (1987) Diagenetic palaeotemperatures from aqueous inclusions: re-equilibration of inclusions in carbonate cements by burial heating. Mineralogical Magazine, 51, 477-81.

Carroll JJ, Slupsky JD, Mather AE (1991) The solubility of carbon dioxide in water at low pressure. Journal of Physical Chemistry Reference Data, 20, 1201-9.

Colmenero JR, Prado JG (1993) Coal basins in the Cantabrian Mountains, north-western Spain. International Journal of Coal Geology, 23, 215-29.

Corretgé LG, Suárez O (1990) Cantabrian and Palentian zones: igneous rocks. Pre-Mesozoic Geology of lberia (eds Dallmeyer RD, Martinez Garcia F). Springer, Heidelberg. pp. 72-79.

Crespo et al. (2000) The Salamon gold deposit (León, Spain). Journal of Geochemical Exploration, 71, 191-208.

Duan Z, Møler N, Weare JH (1996) A general equation of state for supercritical fluid mixtures and molecular dynamics simulation of mixture $P-V-T-X$ properties. Geochimica et Cosmochimica Acta, 60, 1209-16.

Duan Z, Møller N, Weare JH (1992a) An equation of state for the $\mathrm{CH}_{4}-\mathrm{CO}_{2}-\mathrm{H}_{2} \mathrm{O}$ system. Part I. Pure systems from 0 to $1000^{\circ} \mathrm{C}$ and 0-8000 bar. Geochimica et Cosmochimica Acta, 56, 2605-17.

Duan Z, Møller N, Weare JH (1992b) An equation of state for the $\mathrm{CH}_{4}-\mathrm{CO}_{2}-\mathrm{H}_{2} \mathrm{O}$ system. Part II. Mixtures from 50 to $1000^{\circ} \mathrm{C}$ and 0-1000 bar. Geochimica et Cosmochimica Acta, 56, 2619-31.

Dubessy J, Audeoud D, Wilkins R, Kosztolany C (1982) The use of the Raman Microprobe Mole in the determination of the electrolytes dissolved in the aqueous phase of fluid inclusions. Chemical Geology, 37, 137-50.

Dubessy J, Poty B, Ramboz C (1989) Advances in C-O-H-N-S fluid geochemistry based on micro-Raman spectrometric analysis of fluid inclusions. European Journal of Mineralogy, 1, 517-34.

Fisher D, Byrne T (1990) The character and distribution of mineralised fractures in the Kodiak Formation, Alaska: implications for fluid flow in an underthrust sequence. Journal of Geophysical Research, 95, 9069-80.

Foley NK, Bethke PM, Rye RO (1989) A reinterpretation of the $\pi \mathrm{DH}_{2} \mathrm{O}$ of inclusion fluids in contemporaneous quartz and sphalerite, Creede mining district, Colorado. Economic Geology, 84, 1966-77.

Frings KH (2002) Palaeotemperature anomalies in late-Variscan coal basins, Ciñera-Matallana basin, Cantabrian Zone, NW Spain. $G A E A$ heidelbergensis (in press).

Gálan E, Aparicio A, Villegas FJ (1978) El metamorfismo de muy bajo grado (Anquimetamorfismo) de la Cuenca Carbonífera Ciñera-Matallana, León. Estudios Geológicos, 34, 505-10.

García López S, Bastida F, Brime C, Aller J, Valín ML, Sanz-López J, Méndez CA, Menéndez-Álvarez JR (1999) Metamorphic episodes 
in the Cantabrian Zone and their structural context. Trabajos de Geologia , 21, 177-87.

Goldstein RH (1986) Re-equilibration of fluid inclusions in lowtemperature calcium carbonate cement. Geology, 14, 792-5.

Goldstein RH, Reynolds TJ (1994) Systematics of fluid inclusions in diagenetic minerals. SEPM Short Course 31.

Gratier JP (1982) Experimental and natural approach to the deformation of rocks by dissolution-crystallisation, with material transfer. Bulletin de Mineralogie, 105, 291-300.

Gratier JP, Jenatton L (1984) Deformation by solution-deposition, and re-equilibration of fluid inclusions in crystals depending on temperature, internal pressure and stress. Journal of Structural Geology, 6, 189-200.

Haar L, Gallagher JS, Kell GS (1984) Steam Tables, thermodynamic and transport properties and computer programs for vapour and liquid state of water. In: SI Units. Hemisphere Publishing, Washington, DC.

Hurai V, Horn E-E (1992) A boundary layer-induced immiscibility in naturally reequilibrated $\mathrm{H}_{2} \mathrm{O}-\mathrm{CO}_{2}-\mathrm{NaCl}$ inclusions from metamorphic quartz (Western Carpathians, Czechoslovakia). Contributions to Mineralogy and Petrology, 112, 414-27.

Knight JA (1983) The stratigraphy of the Stephanian rocks of the Sabero Coalfield, León, NW Spain), and an investigation of the fossil flora. Part I. The stratigraphy and general geology of the Sabero Coalfield. Paleontographica (Stuttgart), Abt. B, $187,1-88$.

Kronenberg AK, Kirby SH, Ames RD, Rossman GR (1986) Solubility and diftusional uptake of hydrogen in quartz at high water pressures; implications for hydrolytic weakening. Journal of Geophysical Research, B, Solid Earth and Planets, 91, 12723-41.

Krumgalz BS, Pogoreisky R, Pitzer KS (1996) Volumetric properties of single aqueous electrolytes from zero to saturation concentrations at $298.15 \mathrm{~K}$ represented by Pitzer's Ion-Interaction Equation. Journal of Physical Chemistry Reference Data, 25, 663-89.

Küster M, Stöckhert B (1997) Density changes of fluid inclusions in high-pressure low-temperature metamorphic rocks from Crete: a thermobarometric approach based on the creep strength of host minerals. Lithos, 41, 151-67.

Lacazette A (1990) Application of linear elastic fracture mechanics to the quantitative evaluation of fluid-inclusion decrepitation. Geology, 18, 782-5.

Lee BI, Kesler MG (1975) A Generalised Thermodynamic Correlation Based on Three-Parameter Corresponding States. American Institute of Chemical Engineering Journal, 21, 510-527.

Leroy J (1979) Gauging the internal pressure of fluid inclusions during decrepitation. Bulletin of the de Mineralogie, 102, 584-93.

Lobato L, Garciá Alcalde JL, Sánchez de Posada LC, Truyols J, Villegas FJ (1984) Hoja del Mapa geológico de España E. 1: 50.000 no. 104 (BOÑAR). 2 Serie Magna, IGME.

Méndez Cecilia AJ (1985) Estudio de la Evolución de Los Carbones de la Cuenca Ciñera-Matalana, León. Unpublished PhD Thesis, University Oviedo, León, 269pp.

Naden J (1996) CalcicBrine; a Microsofi Excel 5.0 add-in for calculating salinities from microthermometric data in the system $\mathrm{NaCl}-\mathrm{CaCl}_{2} \cdot \mathrm{H}_{2} \mathrm{O}$. Program and Abstracts, Biennial Pan-American Conference on Research on Fluid Inclusions, 6, 97-8.

Osborne M, Haszeldine RS (1993) Evidence for resetting of fluid inclusion temperatures from quartz cements in oilfields. Marine and Petroleum Geology, 10, 233-9.

Osborne M, Haszeldine RS (1995) Discussion: Evidence for resetting of fluid inclusion temperatures from quartz cements in oilfields. Marine and Petroleum Geology, 12, 559-75.
Pêcher A (1981) Experimental decrepitation and re-equilibration of fluid inclusions in synthetic quartz. Tectonophysics, $\mathbf{7 8}$, 565-76.

Pérez-Estaun A, Bastida F, Alonso JL, Marquínez J, Aller J, Alvarez-Marrón J, Marcos A, Pulgar JA (1988) A thin-skinned tectonic model for and arcuate fold and thrust belt: the Cantabrian Zone (Variscan Ibero-Armorican Arc). Tectonics, 7(3), 517-37.

Pulgar FJ, Alonso JL, Espina RG, Marín JA (1999) The alpine deformation in the Variscan basement of the Cantabrian Zone. Trabajos de Geologia, 21, 283-94.

Rettich TR, Handa YP, Baffino R, Wilhelm E (1981) Solubility of gases in liquids. 13. High precision of Henry's constants for methane and ethane on liquid water at $275-328 \mathrm{~K}$. Journal of Physical Chemistry, 85, 3230-7.

Roedder E (1984) Fluid Inclusions (Reviews in Mineralogy 12). Geological Society of America, Washington, DC.

Samson IM, Walker RT (2000) Cryogenic Raman Spectroscopic studies in the system $\mathrm{NaCl}-\mathrm{CaCl}_{2}-\mathrm{H}_{2} \mathrm{O}$ and implications for lowtemperature phase behaviour in aqueous fluid inclusions. Canadian Mineralogist, 38, 35-43.

Setzmann U, Wagner W (1991) A new equation of state and tables of thermodynamic properties for methane covering the range from the melting line to $625^{\circ} \mathrm{K}$ at pressure up to $1000 \mathrm{MPa}$. Journal of Physical Chemistry Reference Data, 20, 1061-115.

Soave G (1972) Equilibrium constants from a modified RedlichKwong equation of state. Chemical Engineering Science, 27, 1197-203.

Spötl, Pitman (1998) Saddle (Baroque) Dolomite in Carbonates and Sandstones: a Reprisal of a Burial Diagenetic Concept. Special Publications of the International Association of Sedimentology, 26, 437-60.

Sterner SM, Bodnar RJ (1989) Synthetic fluid inclusions. Part VII. Re-equilibration of fluid inclusions in quartz during laboratorysimulate metamorphic burial and uplift. Journal of Metamorphic Geology, 7, 243-60.

Sterner SM, Hall DL, Keppler H (1995) Compositional reequilibration of fluid inclusions in quartz. Contributions to Mineralogy and Petrology, 119, 1-15.

Swanenberg HEC (1980) Fluid Inclusions in High-Grade Metamorphic Rocks from SW Norway. PhD Thesis, Geol. Ultraiectina, University Utrecht, 25 147pp.

Thiery R, Vidal J, Dubessy J (1994) Phase equilibria modelling applied to fluid inclusions; liquid-vapour equilibria and calculation of the molar Volume in the $\mathrm{CO}_{2}-\mathrm{CH}_{4}-\mathrm{N}_{2}$ system. Geochimica et Cosmochimica Acta, 58, 1073-82.

Villegas FJ (1996) Exploración E Investigación de un Nuevo Yacimento de Carbón En la Cuenca Minera Ciñera-Matallana (León). Unpublished PhD Thesis, University Complutense, Madrid, 417pp.

Vityk MO, Bodnar RJ (1995) Textural evolution of synthetic fluid inclusions in quartz during re-equilibration, with application to tectonic reconstruction. Contributions to Mineralogy and Petrology, 121, 309-23.

Vityk MO, Bodnar RJ, Dudok IG (1995) Natural and synthetic reequilibration textures of fluid inclusions in quartz (Marmarosh Diamond): evidence for refilling under conditions of compressive loading. European Journal of Mineralogy, 7, 1071-87.

Vityk MO, Bodnar RJ, Dudok IG (1996) Fluid inclusions in "Marmarosh Diamonds": evidence for tectonic history of the Folded Carpathian mountains, Ukraine. Tectonophysics, 255, 163-74.

Vityk MO, Bodnar RJ, Schmidt CS (1994) Fluid inclusions as tectonothermobarometers: relation between pressure-tempera- 
ture history and re-equilibration morphology during crustal thickening. Geology, 22, 731-4.

Wagner RH (1971) The stratigraphy and structure of the CiñeraMatallana Coalfield (Province of León, NW Spain). Trabajos de Geología, 4, 385-429.

Wagner RH, Artieda JI (1970) La Cuenca Minera CiñeraMatallana. S.A. Hullera, Vasco Leonesa.
Wagner W, Pruss A (1993) International equations for the saturation properties of ordinary water substances. Revised according to the international temperature scale of 1990. Addendum to Journal of Physical Chemistry Reference Data, 16, 783-7.

Wilson CJL (1994) Crystal growth during a single-stage opening event and its implications for syntectonic veins. Journal of Structural Geology, 16, 1283-96. 